\title{
'We have been Informed that the French are Carrying Desolation Everywhere': The Desolation of the Palatinate as a European News Event
}

\author{
Emilie Dosquet
}

\begin{abstract}
After the fall of Philippsburg, the Dauphin went into the Palatinate which he subjugated entirely. He seized by Siege Manheim, Frankenthal \& Heidelberg. The towns of Worms, Spire, Oppenheim \& many others opened their Doors without resistance. But these towns of Worms, Spire \& Oppenheim, which gave themselves up to the French, \& prided themselves on being treated according to the common laws of War, experienced a cruel fate, more terrible than that of Heidelberg; because they were not only completely destroyed and consumed with fire, but besides that, the overly credulous Inhabitants, who had taken their main personal effects to put them in a safe place, fell prey to pillage \& the fury of the Soldier. Since we have seen the description of it in the public News, I will skip the details of the cruelties \& inhumanities which are capable of touching the most insensitive hearts. ${ }^{1}$
\end{abstract}

Borrowed word for word from the eleventh issue of the "historical and political mercure" Lettres sur les matières du temps dated 15 June 1689, these few lines of Henri de Limiers' Histoire de Louis XIV constitute a narrative of what the author

1 [Henri de Limiers], Histoire de Louis XIV. Roi de France et de Navarre. Où l'on trouve une Recherche éxacte des Intrigues de cette Cour dans les principaux Etats de l'Europe. Par H. P. D. L. D. E. D. (Amsterdam, 1717), vol. 4, p. 282: "Après la prise de Philipsbourg, le Daufin entra dans le Palatinat qu'il réduisit entièrement. Il s'empara de Manheim, de Frankenhal \& d'Heidelberg par des Sièges formez. Les Villes de Worms, de Spire, d'Oppenheim, \& quantité d'autres ouvrirent ensuite leurs Portes, sans faire aucune résistance. Mais ces mêmes Villes de Worms, Spire \& Oppenheim, qui s'étoient rendues aux François, \& qui s'étoient flatées qu'on ne les traiteroit que selon les Loix ordinaires de la Guerre, éprouvèrent néanmoins une destinée cruelle \& plus terrible, que ne fut celle d'Heidelberg; puisque non seulement elles furent entièremen détruites \& consumées par le feu; mais qu'outre cela les Habitans trop crédules, qui en avoient emporté leurs principaux éfets pour les mettre en sureté, furent la proïe du pillage \& de la fureur du Soldat. Comme on en a vû la description dans les Nouvelles publiques; je passerai sur ce détail de cruautez \& d'inhumanitez capables de toucher les cœurs les plus insensibles".

(C) EMILIE DOSQUET, 2016 | DOI 10.1163/9789004277199_029

This is an open access chapter distributed under the terms of the Creative Commons Attribution-

Noncommercial-NoDerivatives 3.o Unported (CC-BY-NC-ND 3.0) License. 
called "the hostilities of France against the Empire" at the beginning of the Nine Years War (1688-97). ${ }^{2}$ By placing news at the heart of history with a mise en abyme between historical writing and periodical writing, this narrative brings the reader, almost 30 years after the fact, from "public News" to history through printed news, into the making of a historical event, namely the desolation of the Palatinate.

Having besieged Philippsburg and taken the principal fortress-cities and walled towns on the Rhine in autumn 1688, the Sun King's army implemented a large-scale, systematic scorched-earth policy from Cologne to Freiburg, combining three well-known tactics of the time: tax collection, ravages, and the dismantling of fortifications. ${ }^{3}$ This strategy, ordered by Louis XIV and based on the importance of logistical issues for the European warfare of the time, had a double objective. ${ }^{4}$ The first was fairly standard: to supply his own army while disrupting the enemy's supplies and communications. But primarily, in the context of a global policy of 'aggressive defence'

2 Lettres sur les matières du temps (LMT), vol. 2 (15Juin 1689), pp. 178-9. On this specific editorial object, see Marion Brétéché, Les Compagnons de Mercure. Journalisme et Politique dans L'Europe de Louis XIV (Seyssel: Champ Vallon, 2015). On this conflict, see: Geoffrey Symcox, 'Louis XIV and the Outbreak of the Nine Years War', in Louis XIV and Europe, ed. Ragnhild Hatton (Columbus, он: Ohio State University Press, 1976), pp. 179-212; Charles Boutant, L'Europe au grand tournant des années 1680. La succession palatine (Paris: CDU SEDES,1985); Karl Otmar von Aretin, Das alte Reich 1648-1806, 4 vols. (Stuttgart: Klett-Cotta, 1993), vol. 2, pp. 15-51; John A. Lynn, The Wars of Louis XIV, 1667-1714 (London: Routledge, 1999), pp. 191-265.

3 Camille Rousset, Histoire de Louvois et de son administration politique et militaire (Paris: Didier et cie., 1862-3), vol. 4, pp. 58-26o; Hans B. Prutz, 'Louvois und die Verwüstung der Pfalz 1688-1689', Deutsche Zeitschrift für Geschichtswissenschaft, 4 (1890), pp. 239-74; Kurt von Raumer, Die Zerstörung der Pfalz von 1689 im Zusammenhang der französischen Rheinpolitik (1930; Bad Neustadt: D. Pfaehler 1982); Michèle Fogel, 'La désolation du Palatinat ou les aléas de la violence réglée (septembre 1688-juin 1689)', in Guerre et répression. La Vendée et le Monde (Nantes : Ouest Éditions, 1993), pp. 111-7; Hermann Weber, 'La stratégie de la terre brûlée: le cas du Palatinat en 1689', in La Vendée dans l'histoire, ed. Alain Gérard and Thierry Heckmann (Paris: Perrin, 1994), pp. 193-208; John A. Lynn, 'A Brutal Necessity? The Devastation of the Palatinate, 1688-1689', in Civilians in the path of War, ed. Mark Grimsley and Clifford Rogers (Lincoln, NE: University of Nebraska Press, 2002), pp. 79-110; JeanPhillipe Cénat, 'Le ravage du Palatinat: politique de destruction, stratégie de cabinet et propagande au début de la guerre de la Ligue d'Augsbourg', Revue historique, 631 (2005), pp. $97^{-132 .}$

4 Martin van Creveld, Supplying War: Logistics from Wallenstein to Patton (Cambridge: Cambridge University Press 1997), pp. 5-39; John A. Lynn, 'Food, Funds, and Fortresses. Resource Mobilization and Positional Warfare in the Wars of Louis XIV', in Feeding Mars: Logistics in Western Warfare from the Middle Ages to the Present, ed. John A. Lynn (Boulder, co: Westview Press, 1993), pp. 137-59. 
since the Dutch War $(1672-9)$ that aimed to protect the French territory by securing its borders, the Sun King wanted to establish a true 'buffer zone' to prevent any enemy intrusion into the realm. ${ }^{5}$ As soon as they occupied the main part of the Upper and Middle Rhine territories of the Holy Roman Empire, the French troops levied so-called contributions-namely taxes in cash and in kind-which they enforced with hostages and the threat of burning. ${ }^{6}$ French troops also conducted several raids in unoccupied territories on the right bank of the Rhine, as far away as Swabia and Franconia. From October, Louis XIV and his Secretary of State for War Louvois planed the imminent retreat to the line of French citadels on the Rhine's left bank. At this point, the officers were ordered to ravage the country and destroy all unused resources to deprive the enemy of any means of subsistence. Above all, Louis went to the extreme of planning and implementing the complete destruction of the main strategic fortress-cities and walled towns, foremost among them Heidelberg, Mannheim, Speyer and Worms. This strategy was implemented from the Electorates of Trier, Cologne and Mainz in the north to the Margraviates of Baden and the Duchy of Württemberg in the south, mostly in the Electoral Palatinate as well as the bishoprics of Worms and Speyer. But a precise geography, as well as an accurate chronology, is hard to establish. This systematic destruction was carried out for nearly a year, between the autumn of 1688 and the autumn of 1689 . Nevertheless, small operations were waged occasionally over the next several years, until the invasion of 1693 and the second destruction of Heidelberg. ${ }^{7}$

5 André Corvisier, 'Louis XIV et la guerre. De la politique de grandeur à la défense nationale', in L'État classique, 1652-1715, ed. Henri Méchoulan and Joël Cornette (Paris: Vrin, 1996), pp. 261-80; Raumer, Die Zerstörung der Pfalz, pp. 98-113.

6 Fritz Redlich, De Praeda Militari. Looting and Booty 1500-1815 (Wiesbaden: Franz Steiner, 1956); Ronald T. Ferguson, 'Blood and Fire. Contribution Policy of the French Armies in Germany (1668-1715)', PhD thesis (University of Minnesota, 1970), pp. 56-122; John A. Lynn, 'How War Fed War: The Tax of Violence and Contributions during the Grand Siècle', Journal of Modern History, 65 (1993), pp. 286-310.

7 Der Franzoseneinfall 1693 in Südwestdeutschland. Ursachen, Folgen, Probleme, ed. Gerhard Fritz and Roland Schurig (Remshalden-Buoch: M. Hennecke, 1994); Gerhard Fritz, 'Südwestdeutschland und das Franzosenjahr 1693', Zeitschrift des Historischen Vereins für das wirtembergische Franken, 79 (1995), pp. 117-48; Roland Vetter, Heidelberga deleta. Heidelbergs zweite Zerstörung im Orléansschen Kriege und die französische Kampagnevon 1693 (Heidelberg: B. Guderjahn, 1990); Roland Vetter, “Toute la ville est bruslée”. Heidelbergs Zerstörung 1693. Militärische und politische Ziele Frankreichs im fünften Jahr des Pfälzischen Erbfolgekrieges', Badische Heimat, 76 (1996), pp. 359-75. 
This "extreme application of standard military practices" shocked the Sun King's contemporaries. ${ }^{8}$ Indeed, as soon as they occurred, these military operations were brought to the attention of the European public in various forms of printed news - periodicals, accounts, broadsheets, pamphlets, and so onmostly in French, English, German and Dutch. Those reports raised a scandal and the facts they described became a meaningful and distinct episode in the war, known today as the devastation or desolation of the Palatinate. These series of French military operations thus constituted an event, i.e. an historical unit, which is detached from the everyday continuity of the war and seen instead as a remarkable discontinuity. The event emerged from a process that united a series of geographically and chronologically scattered military actions under a common name. To understand this event, it is necessary to unpick the process of its construction, in which print plays an essential role. Indeed, the event resulted both from the fact that the French military operations belonged to a coherent strategy and that as soon as they occurred, they became integrated within news networks, which processed them on several scales. In a media landscape characterised by interdependence, intermediality and intertextuality, the work of unpicking this construction rests on a cross-analysis of the shape and spread of printed news on local, national and international scales to highlight the role of the many exchanges, mostly intertextual-both intra- and intermedia-which characterised news networks, and contributed to the making of so-called "European" news. Because of their asserted European nature, the remarkable resonance of the French military operations enables us to examine the impact of a developing information network in Europe and to comprehend the shape of so-called transnational news: that is, news resulting from systemic exchanges on different scales. ${ }^{9}$ This assertion also allows us to assess the European dimension of a gathering opposition to Louis XIV from the 1670 s, an opposition in which historians have noted "a remarkably uniform ideology".10 This paper offers

8 Lynn, 'A Brutal Necessity?', p. 100.

9 Michael Werner and Bénédicte Zimmermann, 'Penser l'histoire croisée: entre empirie et réflexivité', Annales Hss, 1 (2003), pp. 7-36, esp. 22-3.

10 On the gathering anti-French opposition during the reign of Louis XIV, and in particular concerning the print production, see, e.g.: Pieter J.W. Van Malssen, Louis XIV d'après les pamphlets répandus en Hollande (Paris and Amsterdam: H.J. Paris/A. Nizet and M.Bastard, 1937); Joseph Klaits, Printed Propaganda Under Louis XIV: Absolute Monarchy and Public Opinion (Princeton: Princeton University Press, 1976); Peter Burke, The Fabrication of Louis XIV (Bath: Bath Press, 1994), 135-49; Steven C.A. Pincus, 'From Butterboxes to Wooden Shoes: The Shift in English Popular Sentiment from AntiDutch to anti-French in the 167os', The Historical Journal, 38 (1995), pp. 333-61; Hans 
avenues of analysis for an "histoire croisée" or "cross-history" of an event within the "media tetrahedron" of early modern Europe-i.e. England, France, the Dutch Republic and the Holy Empire-with the aim both of apprehending the process by which the event was constructed, and of discussing its characterisation as "European".11

At a time when the flow and density of information were increasing, the periodical nature and text structure of printed news were fundamental to an understanding of the constitution of the French military depradations as an event. ${ }^{12}$ In this regard, weekly periodicals, which were the first printed news publications that reported facts with reasonably high frequency and regularity - once to five times a week, depending on the periodicity of the newspapers - played an essential role in the making of the event. For clarity and representativeness, this study will be based initially on a French-language gazette, the biweekly Nouveau Journal Universel-ancestor of the famous Gazette d'Amsterdam - published in Amsterdam by two exiled Huguenots,

Bots, 'L'image de la France dans les Provinces-Unies', in L'État classique, 1652-1715, ed. Méchoulan and Cornette, pp. 341-53; Krieg der Bilder. Druckgraphik als Medium politischer Auseinandersetzung im Europa des Absolutismus, ed. Wolfgang Cilleßen (Berlin: DHM, 1997), esp. pp. 95-206, 317-41; Jean Schillinger, Les pamphlétaires allemands et la France de Louis XIV (Bern: Peter Lang, 1999); Martin Wrede, Das Reich und seine Feinde. Politische Feindbilder in der reichspatriotischen Publizistik zwischen Westfälischem Frieden und Siebenjährigem Krieg (Mainz: Vandenhoeck \& Ruprecht, 2004), 324-545; Tony Claydon, Europe and the Making of England 1660-1760 (Cambridge: Cambridge University Press, 2007), 152-92; Isaure Boitel, 'Du barbare à l'oppresseur décrépi. L'image de Louis XIV guerrier dans les satires anglaises et hollandaises', Cahiers de la Méditerranée, 83 (2011), pp. 125-34; Charles-Edouard Levillain, Vaincre Louis XIV. Angleterre-Hollande_France (Paris: Champ Vallon, 2010); Hendrik Ziegler, Der Sonnenkönig und seine Feinde. Die Bildpropaganda Ludwigs XIV. in der Kritik (Petersberg: Imhof, 2010); Donald Haks, Vaderland en vrede, 1672-1713. Publiciteit over de Nederlandse republiek in oorlog (Hilversum: Verloren, 2013), esp. pp. 21-57; Klaits, Printed Propaganda, p. 22.

11 Werner and Zimmermann, 'Penser l'histoire croisée', pp. 7-36; Johannes Arndt, 'Die europäische Medienlandschaft im Barockzeitalter', in Auf dem Weg nach Europa. Deutungen, Visionen, Wirklichkeiten, ed. Irene Dingel (Göttingen: Vandenhoeck \& Ruprecht, 2010), 25-40; Thomas Weißbrich and Horst Carl, 'Präsenz und Information: Frühneuzeitliche Konzeptionen von Medienereignisse', in Europäische Wahrnehmungen 1650-1850. Interkulturelle Kommunikation und Medienereignisse, ed. Horst Carl and Joachim Eibach (Hannover: Wehrhahn, 2008), pp. 75-98.

Daniel Woolf, 'News, History and the Construction of the Present in Early Modern England', in The Politics of Information in Early Modern Europe, ed. Brendan Dooley and Sabrina A. Baron (London: Routledge, 2001), pp. 80-118. 
Claude Jordan and Jean Tronchin du Breuil.13 The Nouveau Journal Universel was one of the most important French-language gazettes regularly published in the Dutch Republic at the beginning of the Nine Years War. ${ }^{14}$ These Frenchlanguage gazettes or "gazettes de Hollande" were the most international periodical of the time, emerging from the Dutch book trade's dynamism in the area of francophone production. ${ }^{15}$ This made the Dutch Republic the centre

13 Jean Sgard, 'Gazette d'Amsterdam 2', in Dictionnaire des journaux, ed. Jean Sgard (Oxford and Paris: Volaire Foundation, 1991); Hans Bots, 'La Gazette d'Amsterdam entre 1688 et 1689: Titres, éditeurs, privilèges et interdictions', in Les gazettes européennes de langue française (XVIIL-XVIIIe siècles), ed. Henri Duranton, Claude Labrosse and Pierre Rétat (Saint-Étienne: Publications de l'Université de Saint-Étienne, 1992), pp. 31-9; La Gazette d'Amsterdam, miroir de l'Europe au XVIII ${ }^{e}$ siècle, ed. Pierre Rétat (Oxford: Voltaire Foundation, 2001), esp. pp. 15-30; Isabelle H. Van Eeghen, De Amsterdamse boekhandel 1680-1725, 5 vols. (Amsterdam: Stadsdrukkerij, 1960-78), 5: 14-23 and 2: 26-42; Klaits, Printed Propaganda, pp. 77-85; Marianne Couperus, 'Claude Jordan', in Dictionnaire des journalistes, ed. Sgard; Brétéché, Les Compagnons de Mercure, esp. 63, 75-6, 81-2, 90-91, 187-8, 192-3, 277-87 and 297-8; Jean Sgard, 'La dynastie des Tronchin-Dubreuil', in C'est la faute à Voltaire, c'est la faute à Rousseau. Recueil anniversaire pour Jean-Daniel Candaux, ed. Roger Durand (Geneva: Droz, 1997), 13-21; Jean Sgard 'Jean Tronchin du Breuil', in Dictionnaire des journalistes, ed. Sgard; Eric Briggs, 'La famille Tronchin et Jean Tronchin du Breuil, gazetier', in Gazettes et information politique sous l'Ancien Régime, ed. Henri Duranton and Pierre Rétat (Saint-Étienne: Publications de l'Université de Saint-Étienne, 1999), pp. 87-96; Brétéché, Les Compagnons de Mercure, esp. pp. 64-5, 75-6, 88-94, $15^{2-67}, 185^{-6}, 191-7,272-3$.

14 Bots, 'La Gazette d'Amsterdam entre 1688 et 1689', p. 34. More than 20 years ago, with the information he had at the time, Hans Bots considered that we could assume that the Nouveau Journal universel was the only French-language periodical published in the Dutch Republic during the year 1689. Nevertheless it appears that in particular the Nouvelles extraordinaires de divers endroits - also called Gazette de Leyde — was also printed during this time: however, it seems that no issue from this year survives.

15 Eugène Hatin, Les gazettes de Hollande et la presse clandestine aux XVII e ${ }^{e}$ XVIII ${ }^{e}$ siècles (Paris: R. Pincebourde, 1865); Les gazettes européennes de langue française (XVII ${ }^{e}$ et XVIII ${ }^{e}$ siècles); Gazettes et information politique sous l'Ancien Régime; La suite à l'ordinaire prochain. La représentation du monde dans les gazettes, ed. Denis Reynaud and Chantal Thomas (Lyon: Presses Universitaires de France, 1999); La Gazette d'Amsterdam, miroir de l'Europe au xviiie siècle; Graham C. Gibbs, 'The Role of the Dutch Republic as the Intellectual Entrepôt of Europe in the Seventeenth and Eighteenth Centuries', Bijdragen en Mededelingen betreffende de Geschiedenis der Nederlanden, 86 (1971), pp. 323-49; Le Magasin de l'Univers. The Dutch Republic as the Center of the European Book Trade, ed. Christine Berkvens-Stevelinck, Hans Bots, Paul G. Hoftijzer and Otto S. Lankhorst (Leiden: Brill, 1992); Christiane Berkvens-Stevelinck, 'Lédition française en Hollande', in Histoire de l'édition française, Roger Chartier and Henri-Jean Martin (Paris: Fayard, 1984), vol. 2, pp. 403-17; Laura Cruz, 'The Geographic Extent of the Dutch Book Trade in the 17th 
of European information. ${ }^{16}$ These French-language gazettes were, like the English- and German-language weekly newspapers, all made up of seemingly raw information that was juxtaposed to form dated bulletins consisting of a succession of relatively basic utterances, organised in geographical columns with minimal or indeed with no editorial comment. In his work concerning Frenchlanguage gazettes and the notion of event, in particular in his book on Damiens' attempted assassination of Louis XV in 1757 , Pierre Rétat demonstrates that this synchronic and diachronic juxtaposition formed a segmented narrative. ${ }^{17}$ Following similar reasoning, from autumn 1688 and for several months, news periodicals formulated a series of narrative utterances or "micro-narratives" which were, in a more or less fragmented manner, sketching, by their very periodical nature, a narrative of the French military violence in the Rhenish territories that was discontinuous but coherent. In order to give an outline of this narrative sketch or "primary narrative", let us follow it in the Nouveau Journal Universel over a few days, between Thursday 6 and Monday 13 January 1689.18

\section{NEWS FROM THE EMPIRE AND NEIGHBOURING COUNTRIES.}

$\cdots$

Extract from the Letters from Frankfurt of Decemb. 29. 1688.

Rumour has it that the French have mined the doors \& fortifications of Heilbron \& some other Cities to blow them up before abandoning them; it is more certain that they have burned lots of Villages, \& all the hay \& straw that they have found in the Fields of the Country of Wirtemberg.... There are once again 4. Companies of Dragoons that entered Heidelberg. The Delegates, whom this City sends to Paris to complain about the abuses that the Troops commit there, were made most welcome by Madame d'Orleans, and the King has advised them that he will have their case to examined. The French are ruining all the fortifications \& the walls of Manheim, \& getting its ditches filled in: we bring out of it all the cannon \& ordnance. They demand 80ooo. Écus to

Century. An Old Question Revisited', in Boundaries and their Meanings in the History of the Netherlands, ed. Benjamin Kaplan, Marybeth Carlson, and Laura Cruz (Leiden: Brill, 2009), pp. 119-38.

16 Hans Bots, 'Provinces-Unies, centre de l'information européenne au XVII ${ }^{\text {e }}$ siècle', Quaderni del Seicento Francese, 5 (1983), pp. 283-306.

17 Pierre Rétat, L'attentat de Damiens. Discours sur l'événement au XVIII ${ }^{e}$ siècle (Lyon: Presses Universitaires de Lyon, 1979), pp. 15-46.

18 Unless otherwise specified in brackets, dates are given according to the Gregorian calendar. 
the City of Mainz, besides the Contribution that they claim from the Country. ${ }^{19}$

\section{NEWS FROM THE EMPIRE AND NEIGHBOURING COUNTRIES.}

\section{Extract from the Letters from Frankfurt of January 2. 1689.}

All the letters of the surrounding Cities \& States say, that the news of the happy success of the undertaking of His Royal Highness the Prince of Orange comfort them a little for the damage that the French are causing in all this Country. The soldiers are always insolent; but there are those who are more than the others: We send from Mainz, that Mr Bertram, Secretary of the Elector being gone, we have ordered him, that if he did not come back to his home, we will pull it down, \& hang his son whom we are detaining there: it is easy to judge that these are threats made to attract their host, rather than out of any wish to carry it out. There are 3500 . Dragoons who have gone to the County of Ubingen to burn the Country or to claim Contribution. ${ }^{20}$

\section{NEWS FROM THE EMPIRE AND NEIGHBOURING COUNTRIES.} $\cdots$

Extract of the Letters from Frankfurt of January 5. 1689.

19 Nouveau Journal Universel (NJU), 15 (6 January 1689): "Nouvelles De l'Empire et Pais Voisins ... Extrait des lettres de Francfort du 29. Décemb. 1688. Il court le bruit que les Français ont miné les portes et les fortifications de Heilbron et de quelques autres Villes pour les faire sauter avant de les abandonner; il est plus assuré qu'ils ont brûlé quantité de Villages, et tout le foin et la paille qu'ils ont trouvé dans les Campagnes du Pays de Wirtemberg ... Il est encore entré 4. Compagnies de Dragons dans Heidelberg. Les Députés que de cette Ville là a envoyé à Paris pour se plaindre des excès que les Troupes y commettent, ont été fort bien reçus de Madame d'Orléans, et le Roi leur a fait dire qu'il donnerait leur affaire à examiner. Les François font ruiner toutes les fortifications et les murailles de Manheim, et en font combler les fossés : l'on en sort tout le canon et les munitions de guerre. Ils demandent 80ooo. écus à la Ville de Mayence, outre la Contribution qu'ils prétendent du Pays".

$20 \quad$ NJU, 16 (10 January 1689): "Nouvelles de l'Empire et Pais Voisins ... Extrait des lettres de Francfort du 2. Janvier 1689. Toutes les lettres des Villes et États circonvoisins disent, que la nouvelle de l'heureux succès de l'entreprise de Monseigneur le Prince d'Orange, les consolait un peu du dégât que les François font dans tout ce Pays-là. Les Soldats sont toujours insolents; mais il y en a qui le sont plus les uns que les autres : On mande de Mayence, que le Sieur Bertram, Secrétaire de l'Électeur s'étant absenté, on lui a fait faire commandement, que sil ne revenait pas dans sa maison, on l'allait mettre bas, \& pendre son fils qu'on y détient : il est facile de juger que ce sont des menaces plutôt pour attirer leur Hôte, que pour les vouloir mettre en effet. Il y a 3500. Dragons, qui sont allez dans le Comté d'Ubingen, pour brûler le Pays ou le mettre sous Contribution". 
... We have news that as the Saxons approached the French had abandoned Heilbron \& all the Country of Wirtemberg; We wait from it for the specifics with the confirmation: however the public voice is, that the French had blown up the doors \& parts of fortifications of Heilbron, that they had plundered the City, \& set fire to every corner before abandoning it, \& there are Passengers who are saying that they have seen the flames of Churches from over than $2 \&$ a half leagues. Mr de Monclar arrived the past 26th in Speyer:He had seized \& sold all the wine of the Bishopric: $\mathrm{Mr}$ Bel Croy had made an exact account of the incomes of the Lazaret of Speyer: Mr de la Grange had all the papers of the Chamber of Speyer visited which were brought to Strasburg, to see if we could not find anything that concerns the affairs of Burgundy, or other countries, that could be used by the Crown of France on occasion. We made the same search in the Bishopric Archives of the City, \& because the Chancellor was an obstacle to this, the French have forbidden him to make any use of his Office as long as this search was not made.... The Troops, which we said in the previous Journal had crossed the Rhine under the command of Mr de la Breteche, have been in the Country of Nassau \& Solms, where they have burned \& plundered many Villages; \& not satisfied with this cruelty, they have taken the foodstuffs of the Peasants, such as their wheat, their flour, their grain, \& c. \& they have thrown it down pell-mell on the street, \& have blended ashes with the flour, for fear that these good people salvage something from it: it is easy to judge the despair, considering that this treatment makes their condition more miserable than that of galley-slaves. The soldiers have brought the cattle, \& loaded up the horses even with the salted pigs of these wretches. ${ }^{21}$

NJU, 17 (13 January 1689): "Nouvelles De l'Empire et Pais Voisins ... Extrait des lettres de Francfort du 5. Janvier 1689 ... On a nouvelle qu’à l'approche des Saxons, les François avoient abandonné Heilbron et tout le Pays de Wirtemberg : On en attend les particularités avec la confirmation : cependant la voix publique est, que les François avoient fait sauter les portes et parties des fortifications de Heilbron, qu'ils avoient pillé la Ville, et mis le feu aux quatre coins avant de l'abandonner, et il y a des Passagers qui disent avoir vu les flammes des Églises de plus de deux lieues et demie ... M. de Montclar arriva le 26. du passé à Spire : Il a fait confisquer \& vendre tout le vin de l'Évêché : M. Bel Croy a fait un état exact de tout le revenu du Lazaret de Spire : M. de la Grange fait visiter tous les papiers de la Chambre de Spire qui ont été portez à Strasbourg, pour voir si l'on n'y trouvera rien qui concerne les affaires de Bourgogne, ou autres, qui puissent servir à la Couronne de France dans l'occasion. On fait la même perquisition dans les Archives de l'Évêché de la Ville, \& comme le Chancelier y était en obstacle, les François lui ont fait défense de faire aucune fonction de sa Charge, que cette recherche n'ait été faite ... Les Troupes que nous avons dit dans le Journal précédent avoir passé le Rhin sous le 
An event being both the elementary component of a continuity of occurrences (everything that occurred and thus in itself insignificant) and the manifestation of a discontinuity in this continuity of occurrences (and thus noteworthy), the weekly newspaper was the privileged medium of this event dualism. ${ }^{22}$ Indeed, these periodicals continually combine the ordinary and extraordinary. They related facts that were considered noteworthy enough to be printed but at the same time the large majority of them belong to the ordinary political information that constituted the bulk of this type of printed news. Thus alongside accounts of remarkable facts (or facts related as such), weekly newspapers offered a ritualised information, consisting of kings and princes' courts, religious events, aristocratic births and deaths, arrivals and departures of commercial ships and convoys, movements of troops, battles and sieges. War thus belonged to this ordinary political information and accounts of military operations thus constituted an important part of this type of printed news. ${ }^{23}$ Besides, from the earliest examples of printed news, war was a major subject and wartime usually led to an increase in news production. ${ }^{24}$ The ordinary war of the printed news was far from being devoid of violence, and the news also related an ordinary military violence, especially against civilians. As the Nouveau Journal Universel reported, this ordinary military violence consisted of forced billeting of soldiers, raids and contributions.

commandement de M. de la Breteche, ont été dans le Pays de Nassau et de Solms, où ils ont brûlé et pillé plusieurs Villages ; et non contents de cette cruauté, ils ont pris les denrées des Paysans, comme leur bled, leur farine, leurs grains, etc. et l'ont jette dans la rue pêle-mêle, et ont mêlé de la cendre avec la farine, de peur que ces bonnes gens n'en réchappassent quelque chose : il est facile de juger du désespoir, vu que ce traitement rend leur condition plus misérable que celle des Galériens. Les Soldats ont amené le bétail, \& chargé sur leurs chevaux jusqu'aux cochons salez de ces misérables".

Pierre Rétat, 'Les gazettes: de l'événement à l'histoire', Études sur la presse au xviiie siècle, 3 (1978), pp. 23-38.

23 Pierre Rétat, 'Batailles', in La suite à l'ordinaire prochain, pp. 111-22; Stéphane Haffemayer, L'information dans la France du xviie siècle. La Gazette de Renaudot de 1647 à 1663 (Paris: Honoré Champion, 2002), pp. 56-188; Andrew Pettegree, The Invention of News: How the World Came to Know about Itself (New Haven, London: Yale University Press, 2014), esp. pp. 208-28. Sonja Schultheiß-Heinz, Politik in der europäischen Publizistik. Eine historische Inhaltsanalyse von Zeitungen des 17. Jahrhunderts (Stuttgart: Franz Steiner, 2004), pp. 94-6: For the period of the Dutch War, Sonja Schultheiß-Heinz estimates that around $70 \%$ of all news of the three major newspapers she analysed-i.e. French Renaudot's Gazette, English London Gazette, and German Teutscher Kriegs-Kurier-are dealing with military operations and diplomatic activities related to conflicts.

24 See, e.g.: Mario Infelise, 'The War, the News and the Curious: Military Gazettes in Italy', Politics of Information, ed. Dooley and Baron, pp. $216-36$. 
But alongside this a recognisable extraordinary warfare gradually emerges, consisting of what the printed news suggested, implicitly for the most part, was an extraordinary military violence. The key point is not whether this military violence was in fact exceptional, but to notice that it was reported as such. As a result, and in accordance with the event-nature of periodical printed news, which combines apparently exhaustive banality and selective singularity, the newspapers reported the French military operations as a dialectic of ordinary and extraordinary news of the war. Incidentally, the gazetteer noted in the news from The Hague of 12 January that the ongoing military operations disrupted the seasonality of the news: ${ }^{25}$

The news has never been more abundant from all sides than it is at present, because instead of the other years the gazetteers could these days only speak about some winter quarters, some preparations which were made for the Campaign: today we only hear tell of movements, armies that comb the countryside, besiege, take, plunder, burn Cities ... ${ }^{26}$

Although this war-extraordinary was made explicit through the narrative of cities' destructions and the use of a rhetoric of the indescribable, it was the text-structure of printed periodical news which played an essential part in the implicit distinguishing of the French military operations from the ordinary of war. Continuously confronted with the uncertainty of the facts they reported, gazetteers wholly integrated this contingency into their informative function through numerous rhetorical processes. ${ }^{27}$ As the case of Heilbronn shows, the facts under the newswriter's pens became "hesitating realities". ${ }^{28}$ And this permanent formulation of uncertainty defined the foundational distinction between history as "the narrative of things that

25 Jean Sgard, 'Les saisons de la politique d'après les gazettes', Die Vier Jahreszeiten im 18. Jahrhundert (1986), pp. 89-95.

$26 \quad N J U, 17$ (13 January 1689): "Les nouvelles n'ont jamais été plus abondantes de toutes parts qu'elles le sont présentement, car au lieu que les autres années dans ce temps ici, les nouvellistes ne pouvoient parler que de quelques quartiers d'hiver, de quelques préparatifs qui se faisoient pour la Campagne : aujourd'hui on n'entend parler que de mouvements, que d'Armées qui battent la campagne, assiègent, prennent, pillent, brûlent des Villes".

Claude Labrosse, 'L'incertain et le virtuel. L'événement en perspective dans les gazettes du $18^{\mathrm{e}}$ siècle', in Presse et événement: journaux, gazettes, almanachs (XVIII ${ }^{e}-X I X^{e}$ siècles), ed. Hans-Jürgen Lüsebrink and Jean-Yves Mollier (Bern: Peter Lang, 200o), pp. 7-25; Charlotte Burel, “Le temps lèvera le voile ...": l'écriture du futur', in La suite à l'ordinaire prochain, pp. 53-62.

28 Labrosse, 'Lincertain et le virtuel', p. 10. 
happened" ("le recit des choses avenües") and the gazette as "only the rumour coming from it" ("seulement le bruit qui en court"). ${ }^{29}$ The gazette was the place where the rumour of French military violence-past, present, or future-was repeatedly formulated. While Louis XIV hesitated, over the course of several months, to raze Trier and subject it to the same measures as the other destroyed cities, printed news, issue after issue, related the fear of the inhabitants and the rumour of an eventual razing that did not finally occur. Finally, the repetitive nature of the French military operations, as well as the more lasting quality of the dismantlings themselves, reinforced the repetitive structure of the news that resulted from their text-structure and periodicity. This double repetition helped to represent French strategy as a process of never-ending destruction.

Thus, gradually, with the necessary hindsight, an event-unit detached itself from this dialectic, because, as Reinhart Koselleck writes, "a minimum of 'before' and 'after' constitutes the significant unity that makes an event out of incidents". ${ }^{30}$ Hence, printed news progressively reported the French military actions as part of an ongoing event, which they were shaping by naming it. Thus the news from the Empire of 21 March announced that: "La désolation des Peuples du Palatinat continuë, \& on auroit de la peine de donner ici une juste idée de leur misére." ("The desolation of the Palatinate's People continues, and we can hardly give a good idea of their misery."). ${ }^{31}$ Because they were published monthly rather than weekly, the "historical and political mercures" benefitted even more from this necessary hindsight. ${ }^{32}$ The seventh issue of the Amsterdam Lettres sur les matières du temps of Jean Tronchin du Breuil dated 31 March reads as follows:

Mais je ne puis m'empêcher auparavant de m'arrêter un peu sur un fait des plus remarquables qui vient d'arriver, \& qui ne refute que trop solennellement tout ce qu'on peut alléguer en faveur des desseins \& des intentions de la France : Je parle de la dernière désolation qui vient d'être exercée dans les Villes du Palatinat, \& particulièrement à Heidelberg, lors que les troupes françaises en sortirent le 3 de ce mois, en y laissant des

29 Gazette, Relation des nouvelles du monde receuës tout le mois de mars 1632 (1 April 1632).

$30 \quad$ Reinhardt Koselleck, 'Representation, Event, and Structure', Future Past: On the Semantics of Historical Time (New York: Columbia University Press 2004), p. 106.

$31 \quad$ NJU, 37 (21 March 1689).

32 Myriam Yardeni, 'Journalisme et histoire contemporaine à l'époque de Bayle', History and Theory, 12 (1973), pp. 208-21, esp. 210-20. 
monuments de fureur \& de barbarie, que les précédentes guerres n'avoient point connu. ${ }^{33}$

(I cannot forbear, first of all, dwelling a little upon a very remarkable Thing that has newly happen'd, and which does but too solemnly refute all that can be alleadg'd, in favour of the Designs and Intentions of France. I speak of the late Desolation that has been made in the Cities of the Palatinate, and particularly at Heydelburgh, when that the French Troops departed thence on the $3 d$. of March, leaving there those Monuments of Fury and Barbarity, which former Wars were unacquainted withal.)

In this "historical and political mercure" in the form of an epistolary fiction, the author clearly states the event-nature of the French depradations by asserting their exceptional character and by using the same terminology as previous newspapers to give a name to the facts. Through this act of naming, printed news took part in the crucial process of selection and concentration that progressively made of the facts a whole. ${ }^{34}$ Here, this process went through a geographical simplification focused on the Palatinate. ${ }^{35}$ Indeed, although the other territories affected by more or less important French military operations were mentioned several times, the expression "the Palatinate and other countries" came to be employed more and more often. Furthermore, the newspapers started to publish news directly entitled "From the Palatinate", reinforcing the focus on this geographical space. ${ }^{36}$ The Palatinate, which was central to the French strategy, overshadowed the other Rhenish territories and so gradually became the reference point.

Above all this "primary narrative" was formulated by the cross-border spread of a news network. The newspapers drew in particular upon

33 Madeleine Fabre, 'Lettres sur les matières du temps', in Dictionnaire des journaux; and esp. Brétéché, Les Compagnons de Mercure, esp. pp. 32-6, 188-9, 243-56, 272-3, 308-9; LMT, vol. 2 (31 March 1689), p. 97. See n. 39 below.

34 Jürgen Wilke, 'Choix et représentation d'événements dans la presse allemande du $18^{\mathrm{e}}$ siècle', in Presse et événement, ed. Lüsebrink and Mollier, pp. 65-77; Nina Burkhardt, 'Wie machen Medien ein Ereignis', in Unvergessliche Augenblicke. Die Inszenierung von Medienereignissen, ed. DFG-Graduiertenkolleg 'Transnationale Medienereignisse' (Frankfurt: Societäts-Verlag, 2006), pp. 16-21.

35 We should note the ambiguity of the term "Palatinate", which refers at once to a dynastic space, a territorial space and a geographical space, that are not perfectly equivalent. On this matter, see Hansjörg Probst, Die Pfalz als historischer Begriff (Mannheim: Südwestdt. Verlagsanstalt, 1984).

36 See for example the Habsburg Netherlands' Relations Véritables (RV), but also the Hamburg Nordischer Mercurius (NM). 
correspondents' manuscript newsletters from different countries: therefore printed news was structurally transnational. It belonged to an intertextual network, across languages and spaces, within which it sustained itself by numerous combined exchanges-translations, borrowed expressions, quotations, rewriting, etc. ${ }^{37}$ Thus "the vagaries of news transmission across time and space [were] almost infinite" and so very difficult to identify. Among the multiple mechanisms of news dissemination, which was characterised by varying degrees of rewriting, translation is one of the most important. ${ }^{38}$ For instance, I established that the briefly-appearing London mercure entitled The Dilucidator was in fact a word-for-word English translation of the seven issues of the Lettres sur les matières du temps published originally between January and April 1689 that mentioned the French military operations several times. ${ }^{39}$ However, the mechanisms of news dissemination are rarely so easy to identify. So for example, the "micro-narrative" of the destruction of Heidelberg in the February 1689 issue of the German-language mercure

37 Due to the poor preservation of the archives of gazetteers, their dispersion, and the difficulty of analysing such sources, we know little about the actual writing of the newspapers, the work of the gazetteers and their sources, especially their informers and correspondence networks. See Peter Fraser, The Intelligence of the Secretaries of State and their Monopoly of Licensed News, 1660-1688 (Cambridge: Cambridge University Press, 1956); Jens Gieseler and Thomas Schröder, 'Bestandsaufnahme zum Untersuchungsbereich "Textstruktur, Darstellungsformen und Nachrichtenauswahl", Die Sprache der ersten deutschen Wochenzeitungen im 17. Jahrhundert, ed. Gerd Fritz and Erich Straßner (Tübingen: Walter de Gruyter, 1996), pp. 29-69; Gilles Feyel, L'annonce et la nouvelle. La presse d'information en France sous l'Ancien Régime (1630-1788) (Oxford: Voltaire Foundation, 2000), esp. pp. 172-91; Haffemayer, L'information dans la France du xviie siècle, esp. pp. 467-99; André Belo, 'Nouvelles d'Ancien Régime: la Gazette de Lisbonne et l'information manuscrite au Portugal (1715-1760)', PhD thesis (Ecole des Hautes Etudes en Sciences Sociales, Paris, 2005); François Moureau, La plume et le plomb. Espaces de l'imprimé et du manuscript au siècle des Lumières (Paris: Presses Universitaires ParisSorbonne, 2006), pp. 259-76 and 459-76; Brétéché, Les Compagnons de Mercure, esp. 152-97. For the exchanges constitutive of intratextual networks, see Dooley, 'Introduction', in Dissemination of News, pp. 1-19; Stéphane Haffemayer, 'Transferts culturels dans la

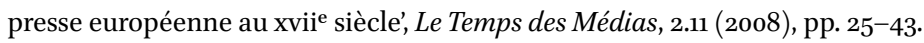

38 Dooley, 'Introduction', in Dissemination of News, p. 15.

39 Carolyn Nelson and Matthew Seccombe, British Newspapers and Periodicals (1641-1700). A short-title Catalogue of Serials printed in England, Scotland, Ireland, and British America (New York: PMLA, 1987), no. 95. Consequently in this article, I have used for the quotations from these seven issues of the Lettres sur les matières du temps the English translation proposed by The Dilucidator. Thus the translation of the previous quotation of the Lettres sur les matières du temps (see n. 33 above) came from The Dilucidator: The Dilucidator, The Sixth Letter (1689), p. 127 . 
entitled Europäischer Mercurius was very similar to that of the 35th issue of Nouveau Journal Universel of 14 March. ${ }^{40}$ Whether this was directly borrowed news, and how many intermediaries it passed through, is impossible to determine. Similarly, there was certainly a link between the Frankfurt news dated 12 December contained in the fourth issue of the Universal Intelligence printed by John Wallis in London, in the context of the Glorious Revolution when a press "without allowance" developed beside the official London Gazette, and that in the 1oth issue of the Nouveau Journal Universel. ${ }^{41}$ Indeed, the first was a short and synthesised version of the second. Was it from the same correspondent? At the very least it was likely to be borrowed news, because John Wallis had seemingly not previously published newspapers and so most probably did not yet have a network of correspondents. But how many rewriting steps and missing links were there between these two versions of the Frankfurt news? Likewise in the London Gazette, the Frankfurt news of 17 March seemed to mix the Frankfurt news of 9 and 17 March from the Relations Véritables - the most important French-language gazette of the Habsburg Netherlands, which played the role of an official organ - and that of 13 March from the Nouveau Journal Universel. ${ }^{42}$ Once more, printed news was rewritten, selected and concentrated through multiple stages of dissemination whose precise nature was hard to determine. But in any case, this complex compilation of borrowed news on which printed periodicals were based played a major part in the making of a shared "primary narrative" of the

40 Europäischer Mercurius. Februarius. Anno M. DC. LXXXIX., 34 (EM); Johannes Weber, Götter-Both Mercurius: Die Urgeschichte der Politischen Zeitschrift in Deutschland (Bremen: Temmen, 1994), pp. 125-33; NJU, 35 (14 March 1689).

Universal Intelligence (18-22 December 1688); Nelson and Seccombe, British Newspapers and Periodicals, no. 644; James Sutherland, The Restoration Newspaper and its Development (Cambridge: Cambridge University Press, 1986), pp. 23-4; Robin B. Walker, 'The Newspaper Press in the Reign of William III', The Historical Journal, 17.4 (1974), pp. 691-709, at 694-5. On the London Gazette, see Fraser, Intelligence of the Secretaries of State, pp. 46-56; Phillys M. Handover, History of the London Gazette, 1665-1965 (London: HMSO, 1965), pp. 9-31; Nelson and Seccombe, British Newspapers and Periodicals, no. 471; NJU, 10 (20 December 1688).

42 London Gazette (LG), no. 2437 (18-21 March 1688); RV (16 Mars 1689 and 23 March 1689); 'Relations Véritables', in Dictionnaire des journaux; Jacques Hellemans, 'L'apparition des gazettes en Belgique: le Postillon ordinaire, la Récite et le Cour(r)ier véritables des PaysBas', in Les gazettes européennes de langue française (XVII ${ }^{e}-X V I I I^{e}$ siècles), pp. 13-21; and especially Paul Arblaster, 'Policy and Publishing in the Habsburg Netherlands, 1585-169o', Politics of Information, ed. Dooley and Baron, pp. 179-98, and From Ghent to Aix: How they Brought the News in the Habsburg Netherlands, 1550-1700 (Leiden: Brill, 2014), pp. 220-55; NJU, 37 (21 March 1689). 
French military operations. Though irreducible dissimilarities existed in the ways news was processed, according to the different publishing paradigms and ideological commitments of editors, they shared a common interest in contemporary events. ${ }^{43}$ Therefore, at a time when commonality was increasing, that is to say that "the number of people simultaneously reading or discussing variants of the same news" expanded, and with it the "potential for contemporaneity", the French military operations, reported by French-, English-, and German-language periodicals, belonged from then on to a kind of cross-boundary 'shared topicality', which manifested, besides dissimilarities, important similarities and points of convergence in the processing of this specific news. ${ }^{44}$

In addition, printed news also laid the foundations of the event-structure by defining its elementary sequences: indeed, an event can be comprehended as textually structured according to a referential narrative thread. ${ }^{45}$ In the case of the French military operations, these elementary sequences of which the event was made up took in particular the form of the destruction of cities. So the referential narrative thread focussed on some of the main fortified towns demolished by Louis XIv's army, namely Heidelberg, Mannheim, Speyer, Worms, and Oppenheim. This "event-sequencing" was also typographically emphasised in the English newspapers, where the names, usually printed in italics, underline this sequencing by cities. Likewise, in the Europäischer Mercurius, the news took the form of a narrative punctuated by the bold and centred names of the various cities reported on in turn: in its

43 See, e.g.: Schultheiß-Heinz, Politik in der europäischen Publizistik; Sonja SchultheißHeinz, 'Contemporaneity in 1672-1679: the Paris "Gazette", the "London Gazette", and the "Teutsche Kriegs-Kurier”, in Dissemination of News, ed. Dooley, pp. 115-35.

44 Woolf, 'News, History and the Construction of the Present', p. 83; Dooley, 'Introduction', in Dissemination of News, p. 2. It is no surprise that Renaudot's Gazette, which played the role of an official organ for the French monarchy, distinguishes itself from the other periodicals by its silences: nevertheless the raids, levies of contributions, military executions, collects of fodder, ravages of the fields, and dismantling of fortifications that are related punctually, here and there in these French printed news, outline the ordinary war (i.e. both the military practices and violence) of the printed news. On Renaudot's Gazette, see Gilles Feyel, 'Gazette [de France]', in Dictionnaire des journaux, ed. Sgard; Feyel, L'annonce et la nouvelle; Haffemayer, L'information dans la France du XVII ${ }^{e}$ siècle.

45 I follow here the remarks of Hans-Jürgen Lüsebrink and Rolf Reichardt on the notion of event based first on their analysis of the storming of the Bastille: Die Bastille. Zur Symbolgeschichte von Herrschaft und Freiheit (Frankfurt: Fischer Taschenbuch, 1990), pp. 59-92; and Hans-Jürgen Lüsebrink, 'Le tremblement de terre de Lisbonne dans des périodiques français et allemands du XVIII ${ }^{\mathrm{e}}$ siècle', in Gazettes et information politique sous l'Ancien Régime, pp. 302-11. 
several 1689 issues, it consecutively related the French military operations to which the Rhenish cities were subjected. Furthermore, in response to the course of French military operations, the printed news reported successively in March the demolition of both Mannheim and Heidelberg, which were linked from the start in the design and implementation of the French strategy, and at the beginning of June the simultaneous destruction of Speyer, Worms and Oppenheim. Hence, the sequencing organised itself also from the start in groups of towns. On 3 June the Marquis de Dangeau, the Sun King's courtier, already noted in his Journal: "On a fait brûler Spire, Worms et Oppenheim" ("We had burned Speyer, Worms \& Oppenheim"). ${ }^{46}$ In his issue dated 30 May (8 June), the important German-language Nordischer Mercurius, published in Hamburg by Friedrich Conrad Greflinger, reported that: "Vergangenen Dienstag haben die Frantzosen die Städte Speyer/ Wormbs und Oppenheim angezündet" ("Last Thursday the French have set fire to the cities of Speyer, Wormbs and Oppenheim and laid them in Ashes"). The Frankfurt news of the 8 June issue of the Relations Véritables announced that: "l'on a vù en flames Openheim, Vorms, Spire, \& autres Places" ("we have seen Openheim, Vorms, Spire, \& other Places in flames"). Likewise the Cologne news in the London Gazette related that the French "have now lately reduced to ashes the Cities of Spire, Worms and Oppenheim, there not being left in these famous Places one House standing". ${ }^{47}$ The section of the 15 June issue of the Lettres sur les matières du temps borrowed by De Limiers referred to this same grouped sequence. And while a German relation relates their simultaneous destruction, ${ }^{48}$ the Europäischer Mercurius designed a similar news sequence announced with a bold and centred heading of "Speyer/ Worms und Oppenheim" to recount it. ${ }^{49}$ Hence this narrative grouping became a typical characteristic of the representation and the narrative of these cities' destruction. In their series of eleven sepia drawings commissioned by the Worms town council to illustrate the account of Worms's demolition, the counsellor Peter Hamman and his son Johann Friedrich chose to

46 Philippe de Courcillon (marquis de Dangeau), Journal du Marquis de Dangeau. Tome deuxième, 1687—1688-1689, ed. Eudore Soulié, Louis Dussieux, Charles-Philippe de Chennevières-Pointel, Paul Mantz and Anatole de Montaiglon (Paris: Firmin Didot Frères, Fils \& Cie, 1854), p. 406.

$47 \quad N M, 84$ (3о May 1689); RV (8 June 1689); LG, 2458 (3o May-3 June 1689).

48 Gründliche und eigentliche Beschreibung Derer Weyland schönen Nun aber Durch unerhörte Grausamkeit der überbarbarischen Franzosen gäntzlich ruinirt-verbrannts- und desolirten Städten Speyer/Worms Und Oppenheim (n.p., 1689). 


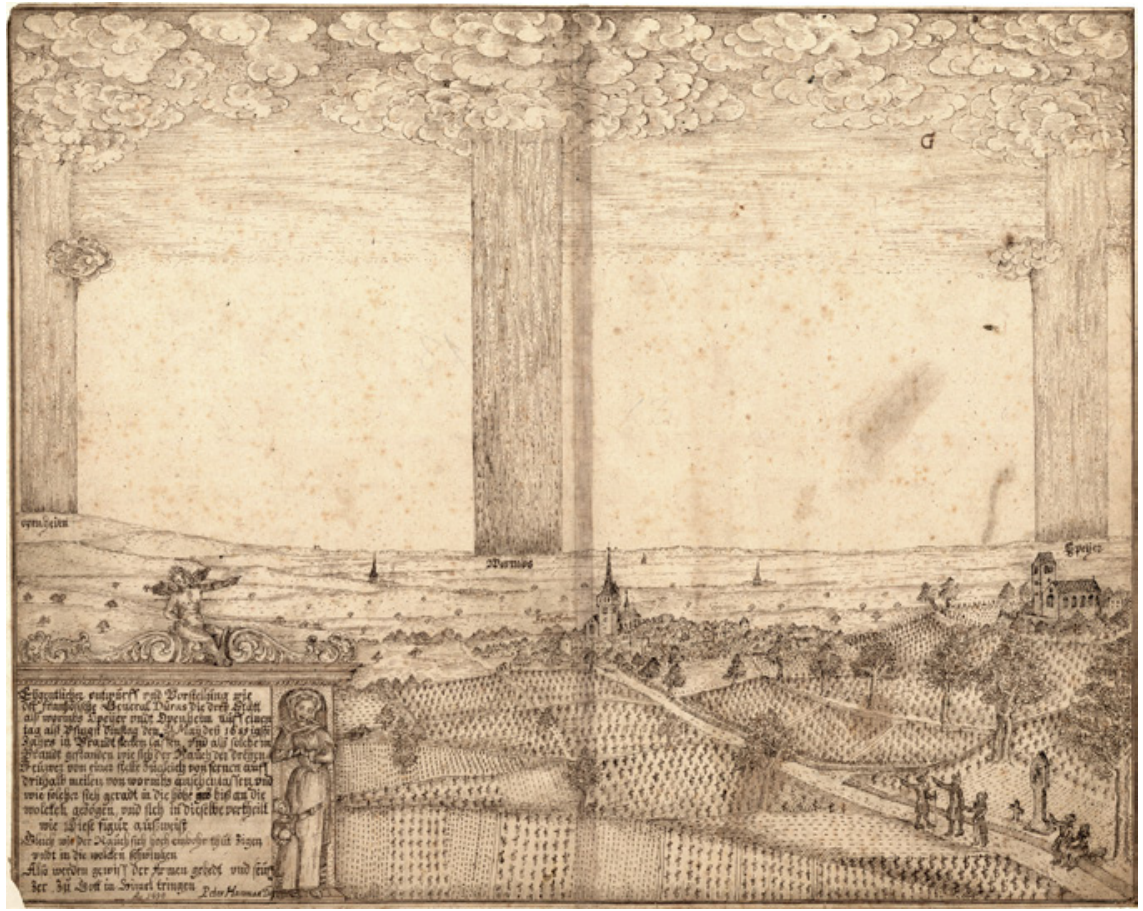

FIGURE 28.1 Stadtarchiv Worms $1 B / 48 G$

represent the triple destruction as an inseparable whole (see Figure 28.1). ${ }^{50}$ Finally this sequencing by cities became in later accounts and pamphlets the basic referential narrative thread of the event. ${ }^{51}$

5o Fritz Reuter, Peter und Friedrich Hamman. Handzeichnungen von Worms aus der Zeit vor und nach der Stadtzerstörung 1689 im 'Pfälzischen Erbfolgekrieg' (Worms: Bessler, 1989).

51 See for example the German account: Die Betrübte und Zerstörte Chur-Pfaltz/welche Die Barbarischen und Tyrannischen Frantzozen an Heydelberg/Mannheim/Speyer/Worms/ Franckenthal und Landau, Mord-brennerisch und unchristlich in die Asche geleget (n.p., 1689); among the pamphlets, see for example an important French-language brochure that was published in 1689, probably in Amsterdam, of which we identified at least three different editions. The edition quoted here is: La Verite Chrestienne a l'audiance de roy tres-Chretien ([Amsterdam?], 1689), pp. 42ff. This brochure was then respectively translated into Dutch and German: De Christelyke Waerheyt, Getoont ter audientie van den Alder-Christelycksten Koning (Amsterdam, 1689), pp. 27ff.; Der Christlichen Warheit gehabte audeins Bey dem Allerchristlichsten König Ludwig dem XIV (n.p., 169o), pp. 33 ff. An English translation also exists that presents very interesting cuts compared to the original version: in particular it mentions Speyer and Worms together but deletes all allusions to Oppenheim: A New Declaration of the Confederate Princes and States, against Lewis the Fourteenth (Londres, 1689), pp. 14ff. 
"Plurimediality" (Plurimedialität) is a fundamental element of the news event. ${ }^{52}$ Here, the making of the event, and especially of the "event-sequencing", resulted from essential exchanges between media. Although the mercures were no simple compilation of the gazettes, they were in line with them. ${ }^{53}$ Likewise, in the German-language area, the publication of some newspaper extracts in the form of independent accounts, as in the case of Speyer's demolition, shows the permeability of editorial forms. ${ }^{54}$ Once again, these inter-media exchanges were transnational. In this regard, the printed accounts of the Rhenish cities' destructions fundamentally influenced the writing of printed news and so contributed to the event-building process on a European scale. Thus the Mannheim town council commissioned an account of the town's destruction from a Hanau printer to be published in both German and French, with 500 copies in each. ${ }^{55}$ French being probably the closest thing to a common European vernacular, printing as well as translating in French indicates a European horizon for a publication. ${ }^{56}$ The prominent case is that of Heidelberg.

$5^{2}$ Horst Carl and Thomas Weißbrich, 'Präsenz und Information: Frühneuzeitliche Konzeptionen von Medienereignisse', in Europäische Wahrnehmungen 1650-1850. Interkulturelle Kommunikation und Medienereignisse, ed. Horst Carl and Joachim Eibach (Hanover: Wehrhahn, 2008), p. 96.

53 Hans Bots, 'Quelques gazettes de Hollande en langue française et le Mercure historique et politique: une analyse comparative', in Gazettes et information politique sous l'Ancien Régime, pp. 159-68; esp. Brétéché, Les Compagnons de Mercure, pp. 190-3-this is the first systematic work on these 'mercures historiques et politique', and on the interrelation between gazettes and mercures.

54 See, e.g.: Extract Aus unterschiedenen Schreiben/Samt einer Relation, Was die Frantzosen in Speyer verwichenen und May verübet haben (n.p., [1689]). On the newspaper extracts as a specific editorial form, see: Esther-Beate Körber, Zeitungsextrakte: Aufgaben und Geschichte einer funktionellen Gruppe frühneuzeitlicher Publizistik (Bremen: Éditions Lumière, 2009).

55 These are very likely the ordered brochures: Relation Und Gründliche Beschreibung der von denen Frantzosen in der Churfürstlichen Pfaltz schön-vor wenig Jahren neu- und durch-auß regular gebauten Stadt Mannheim verübter un-Christlicher Proceduren und erbärmlicher Verwüstung/ im Jahr 1689 (n.p., 1689); La Desolation de la Ville Electorale de Manheim par les François (n.p., [1689]). The town's archive was unfortunately destroyed during the Second World War but this information was (anonymously) published the beginning of the twentieth century: 'Berichte über die Zerstörung Mannheims durch die Franzosen', Mannheimer Geschichtsblätter, 2.7 (1901), pp. 165-6.

56 Pierre-Yves Beaurepaire, Le Mythe de l'Europe française au xviiie siècle: diplomatie, culture et sociabilités au temps des Lumières (Paris: Autrement, 2007), p. 120; Ferdinand Brunot, Histoire de langue française des origines à 1900 (Paris: Armand Colin, 1966), vol. 5, pp. 135-45 and 219-74. 
Introducing a description of Heidelberg's destruction, the author of the previously quoted seventh issue of Lettres sur les matières du temps, addressing his correspondent, wrote: "Vous aurez vu dans les relations publiques" "You may have seen in the publick Relations"). ${ }^{57}$ The author certainly refers here to the anonymously published account of Palatinate councilor Riesman. ${ }^{58}$ Indeed, this account was printed and reprinted multiple times in various forms within the Holy Roman Empire, but above all translated into Dutch and English. ${ }^{59}$ Incidentally, this account may be one of the missing links to understand the abovementioned similarities between the Nouveau Journal Universel and the Europäischer Mercurius. This high degree of visibility in print partly explains how the Heidelberg destruction became representative of all the Rhenish cities' demolition, and more particularly of the French military operations. The Lettres sur les matières du temps presented it in this way, as well the English translation of the original account which was entitled True Account of the Barbarous Cruelties Committed by the French in the Palatinate in January \& February last even though the account related only the French military operations in Heidelberg and around during a single week. So the English account generalised by adopting the geographical focus of the Palatinate and making Heidelberg, the electoral capital, the representative case.

There were also other topoi, besides the destruction of cities, around which the news was sequenced and out of which the destruction of the Palatinate emerged as a distinct event. One example is the plundering of the Speyer imperial graves, which was reported in printed news, and then in a number of

$57 \quad L M T$, vol. 2 (31 March 1689), p.97.

$5^{8}$ Bericht, was die Königl[iche] französische garnison zu Heildeberg unterm commando des Brigadiers Comte de Melac, in denen umb selbige Churfürstliche Residenzstatt gelegenen Stättlein, Flecken und Dorfschafften vom 28ten Jan. biß 3ten Febr. verübet, Generallandesarchiv Karlsruhe: 77/3701, fos. 94-7.

59 Besides at least three editions under this original title, this account was also published under another title, Das Ehmahlig Pracht-gezierte/ Nunmehro Elendig-ruinirte Churfürstliche Residenz-Schloß Heidelberg/(Augsbourg, 1689), and in other forms, such as an illustrated broadsheet (illustriertes Flugblatt): Umständliche Beschreibung Der Französ. Grausamkeit in Heydelberg/ ([Nurnberg], [1689]). Or very often as part of various publications such as accounts and pamphlets, see for example: Die Waagschale der Frantzosen (n.p.,1689), pp. 87-9. The Dutch print was Bericht der Gruweldaden Die door de Besetting, of het Garnisoen van de Keur-Paltse Hofstadt Heydelbergh in dezelve, en de daer onder hoorende Vlecken en Dorpen, onder het commando van den Brigadier den Grave van Melac, zedert den 28 January tot den 3 February 1689 . is bedreven (Amsterdam, [1689]), the English one A True Account of the Barbarous Cruelties Committed by the French in the Palatinate, in January and February last (London, 1689). 
pamphlets, to become in the long term one of the symbolic topoi of the French military violence. ${ }^{60}$ Another interesting example is the topos of the refugee populations displaced by French military operations. Indeed, besides the people who were spontaneously leaving their home to flee the war and the usual military violence, there were numerous refugees due to the demolition of entire cities, towns, and villages. For example, from January 1689, 6,00o inhabitants of Mannheim were ordered to leave their houses with their goods for Alsace before the city was burned in March. ${ }^{61}$ Important refugee communities formed in Strasbourg and Frankfurt in particular. ${ }^{62}$ On 9 June, the Frankfurt news of the Nouveau Journal Universel mentioned: "Il est venu quelques passagers de Spire" ("Some passengers came from Speyer"). On 11 June, the Relations Véritables related that the Rhenish territories were "remplis des débris des gens, dont les flames ont consumé les habitations" ("full of the remnants of people, whose houses the flames had consumed"). The correspondent then referred to "plusieurs centaines de charettes \& de chariots aïant déja passé par ces endroits, sans conter plus grand nombre qui passent encore de l'autre côté du Rhin" ("several hundred carts \& wagons already going through these places, without counting the much larger number which are still going on the other side of the Rhine"). On 16 June, the Frankfurt news of the Nouveau Journal Universel reported that "Ces familles desolées sont déja répanduës dans plusieurs endroits de l'Europe, où elles sont errantes" ("These desolate families are already spread in many places in Europe, where they are wandering"). ${ }^{63}$ The newspapers give here a hint of the importance of word of

6o For the plunder of the Speyer's graves in contemporary periodical news, see e.g. $R V$ ( 16 July 1689);NM, 88 (6June 1689) and 97 (21 June 1689). For pamphlet reporting of the event, see e.g. LaVeriteChrestienne,p.44;anditstranslations:DeChristelykeWaerheyt,p.28;DerChristlichen Warheit, p. 35; A New Declaration, p. 15. For the longer historical view, see e.g. Victor Hugo, 'Lettre XXviI', in Le Rhin, lettres à un ami (Paris: Charpentier, 1845), vol. 2, pp. 317-9.

61 Roland Vetter, 'Kein Stein soll auf dem andern bleiben'. Mannheims Untergang während des Pfälzischen Erbfolgekrieges im Spiegel französischer Kriegsberichte (Heidelberg: Verlag Regionalkultur, 2002), pp. 105-20; and '1685-1689, Zwischen Krise und Krieg', in Geschichte der Stadt Mannheim, ed. Nieß Ulrich and Caroli Michael, vol. 1 (Mannheim: Verlag Regionalkultur, 2007), pp. 238-66.

62 Karl Zinkgräf, 'Mannheimer Flüchtlinge in Weinheim während der Jahre 1689 bis 1697', Mannheimer Geschichtsblätter, 26 (1925), pp. 255-9; and Mannheimer Geschichtsblätter, 27 (1926), pp. 13-6. Wolfgang Hartwich, 'Speyer vom 30 jährigen Krieg bis zum Ende der Napoleonischen Zeit (1620 bis 1814)', in Geschichte der Stadt Speyer, ed. Eger Wolfgang (1982; Stuttgart: Kohlhammer, 1983), pp. 1-100, at 30; Fritz Reuter, 'Der Pfälzische Erbfolgekrieg und die Freie Stadt Worms', in Der Franzoseneinfall 1693 in Südwestdeutschland, ed. Fritz and Schurig, pp. 27-37, here p. 35 .

63 NJU, 60 (9 June 1689); RV (11 June 1689); NJU, 62 (16 June 1689). 
mouth in the dissemination of news and, in this case, most probably of the crucial contribution of the refugees to the spread of news concerning the French military operations. The "miserable refugees" thus became a central figure of the event: in the polemical literature, these "several thousand souls of all ages and sexes who are running around the world" were henceforth described as "the trumpets which are publishing without concealment or exaggeration, the barbarities, the cruelties, the fires, \& the ungodliness that the French committed in the Palatinate" ("Plusieurs milliers d'ames de tout Sexe \& âge qui courent par le monde, font des Trompettes qui publient sans deguisement ni exaggeration, les barbaries, les cruautés, les incendies, \& les impietés que les François ont commis dans le Palatinat".). ${ }^{64}$

Besides the text-structure, news-writing itself necessarily influenced the event-building process. This news-writing corresponds to a stock of textual and iconographic references made up of stereotypes and interpretative patterns, which were used to represent war and violence in early modern Europe. Here, the argument focuses on French-language printed news, but Germanand English-language printed news deployed the same tropes for similar purposes. Among different frames of reference, the biblical was omnipresent: first through the use of the same semantic field as the Old Testament's relation of destruction by a revengeful God who punished sin with devastation; and second, through an eschatological frame of reference based on the Books of Daniel and Revelation. ${ }^{65}$ This last frame of reference is apparent in typical expressions such as the one used by Christ in his eschatological prediction of the destruction of the Temple: "There shall not be left here one stone upon another, that shall not be thrown down" (Matthew 24:2). ${ }^{66}$ From the moment the first orders were issued in the French campaigns this expression was linked

64 La Campagne des Allemans De l'Année 1690 (n.p., 1691), p. 57.

65 Besides episodes from Genesis, such as the destruction of Sodom and Gomorrah, and from Leviticus, the principal biblical references are the Latter Prophets Isaiah, Ezekiel, Jeremiah, and Daniel, and the Minor Prophets, Amos and Hosea.

66 We quote here the King James Bible that is the definitive version for seventeenth-century England. The main German-language catholic Bible of the time-i.e. those of Johannes Dietenberger, Johannes Eck and Caspar Ulenberg — use the word-for-word equivalent by adopting the same passive transitive verbal form, i.e. "kein Stein auf dem andern lassen". The German-language protestant Bible, starting with the Luther Bible, prefers the active intransitive verbal form, i.e. "nicht ein Stein auf dem andern bleiben" ("not one stone remaining upon another"). The French-language Bibles of the time present the same slightly difference but inversely: indeed, the catholic versions prefer the active intransitive verbal form - i.e. "ne pas demeurer pierre sur pierre" — and the protestant version the passive transitive verbal form-i.e. "ne pas laisser pierre sur pierre". 
inextricably with the destruction of Mannheim. Indeed, Louvois announced on 17 November 1688 to the Alsace's intendant, La Grange, that Mannheim would certainly be razed "so that there is not left one stone upon another that could tempt an elector" ("de manière qu'il n'y reste pas pierre sur pierre qui puisse tenter un électeur"), ${ }^{67}$ and in February he used the exact same turn of phrase to hurry the demolition. ${ }^{68}$ On 12 March, the Marquis de Dangeau noted in his Journal about Mannheim that: "on n'y laissera pas pierre sur pierre non plus qu'à la citadelle" ("we will not leave [in the town] one stone upon another, neither in the citadel"). ${ }^{69}$ The expression appeared next in the news report concerning Mannheim's demolition by the French troops. The news "from the Palatinate" of the 8/18 March in Nordischer Mercurius related that: "zumahlen sie Befehl haben/ in Mannheim und Friedrichsburg keinen Stein auff den andern zu lassen" ("above all the French are ordered in Mannheim and Friedrichsburg not to leave one stone upon another"). On 2 April, the Relations Véritables reported that: "il ne reste pierre sur pierre de tant de belles Eglises \& Edifices qu'il y avoit" ("there is not left one stone upon another of so many beautiful Churches \& Buildings"). One week later, the Nouveau Journal Universel reported that the French returned to Mannheim because: "Ils ont ordre de ne pas laisser pierre sur pierre" ("They are ordered not to leave one stone upon another"). Likewise, the so-called "impartial pen" ("unpartheyische Feder") of the Europäischer Mercurius related that they aimed "nach kein Stein auf dem andern bleiben" ("not to leave one stone upon another"). ${ }^{70}$ So the expression spread, attached to the sequence of Mannheim's destruction. ${ }^{71}$

Furthermore, the semantic field of fire- "burn", "reduce to ashes", "consume", and so on — which characterised the French military operations became

67 Defense Historical Service, Vincennes, GR A 871,45 , Letter of Louvois to La Grange, 17 November 1688.

68 Defense Historical Service, Vincennes, GR A1 871, 344, Letter of Louvois to Montclart, 8 February 1689 .

69 Philippe de Courcillon (marquis de Dangeau), Journal du Marquis de Dangeau, p. 351.

$70 \quad N M, 39$ (8 March 1689); RV (2 April 1689); NJU, 42 (7 April 1689); EM, Februarius. Anno M. DC. $L X X X I X$, p. 35 .

71 Die Betrübte und Zerstörte Chur-Pfaltz, p. 8; La Verite Chrestienne, p. 38; and its translations: De Christelyke Waerheyt, p. 25; Der Christlichen Warheit, p. 30. For example, at the beginning of the twentieth century, the French historian Ernest Lavisse wrote about Mannheim's destruction in his Histoire de France in the following terms: "On n'y laissa pas pierre sur pierre" ("We left not there one stone upon another"). Histoire de France depuis les origines jusqu'à la Révolution. Tome huitième: Louis XIV. La fin du règne (1685-1715), ed. Ernest Lavisse (Paris: Hachette, 1908), p. 20. More recently, the German historian Roland Vetter used this phrase for the title of his work on the razing of Mannheim (see n. 61 above). 
predominant in printed news where "French" became a synonym for "incendiaries" (i.e. in its older sense-from the French—of "arsonists"). In German pamphlets, the brigadier Ézéchiel de Mélac, one of the French officers who implemented the operations and appeared regularly in printed news, was referred to as the embodiment of "the French murderous incendiary" ("Frantzösischer Mordbrenner"). Henceforth he was always represented with a lit torch against a background of buildings in flames (see Figure 28.2). ${ }^{72}$ At the same time, as the two engraved frontispieces of both a German and an English pamphlet published in 1690 to denounce the Sun King's policy and the French methods of warfare in particular show, representations of Louis XIV brandishing a lit torch began to appear (see Figures 28.3 and 28.4) ${ }^{73}$ Moreover, in several such references, fire was a diabolical attribute associated with the Antichrist. ${ }^{74}$ In the 28 September 1689 issue of the Relations Véritables, the analogy was obvious to the Mainz correspondent:

Jamais on a oüi parler de tant d'incendies \& de desolation. Il semble que tous ces boutefeux soient les précurseurs du dernier Jugement, ou qu'ils prennent à tache de faire consommer avant le tems, les matières qui pourront servir d'aliment au feu qui viendra purifier le monde ${ }^{75}$

Huge flames rising up to the sky and visible from afar became one of the textual and iconographic aspects of the event. So the seventeenth issue of the Nouveau Journal Universel related that: "il y a des Passagers qui disent avoir vu les flammes des Églises de plus de deux lieues et demie" ("there are Passengers who are saying that they have seen the flames of Churches from further than

72 Sigrid Wechssler, Flugblätter. Aus der Frühzeit der Zeitung. Gesamtverzeichnis der Flugblatt-Sammlung des Kurpfälzischen Museums der Stadt Heidelberg (Heidelberg: Kurpfälzisches Museum, 1980), no. 167; Frieder Hepp, “Weh dir Pfalz". Erfahrungen wiederholter Kriegszerstörungen an Rhein und Neckar', in Kurpfalz und Rhein-Neckar. Kollektive Identitäten im Wandel, ed. Volker Gallé, Jörg Peltzern, Bernd Schneidmüller and Stefan Weinfurter (Heidelberg: Universitätsverlag, 2008), pp. 138-7.

73 Der Frantzösische Attila, Ludovicus XIV (n.p., 169o), and The most Christian Turk: Or, a View of the Life and Bloody Reign of Lewis XIV (London, 169o).

74 This importance of arson in the French military operations was for example also polemically exploited through the image of Phaeton's fall (Ovid, Metamorphoses, I, 750-779 and II, 1-339) that appeared in the print against Louis XIV during the Dutch War. See for example the quotation of Ovid on the front page of $A$ New Declaration (see $\mathrm{n} .5^{1}$ above). See Hendrik Ziegler, Der Sonnenkönig und seine Feinde, pp. 30-4. $R V$ (28 September 1689). 


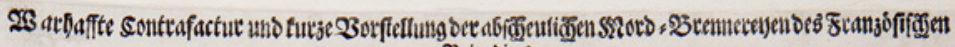

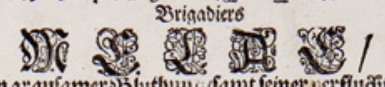

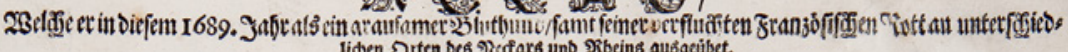

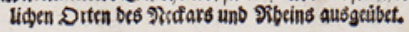

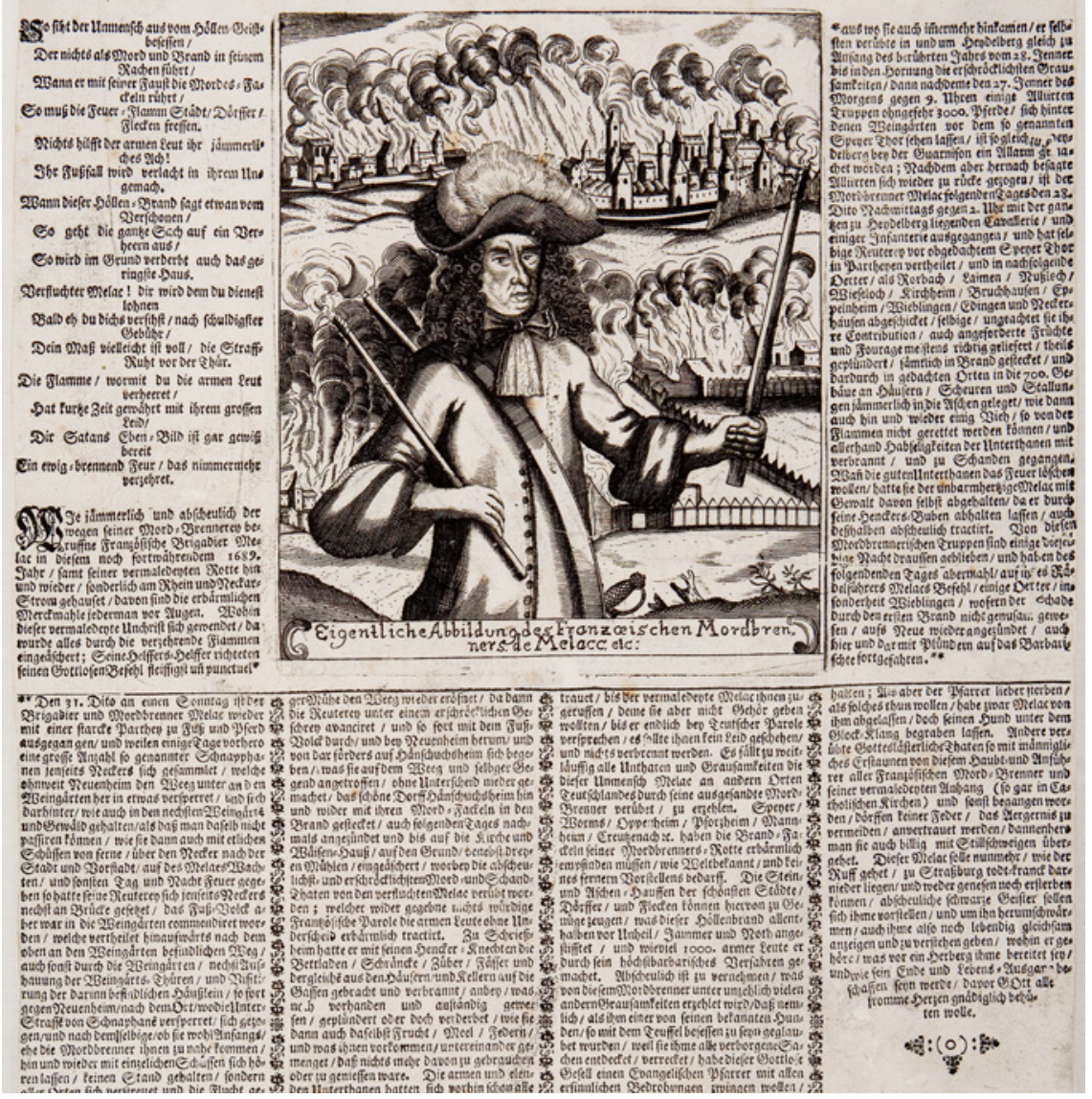

FIGURE 28.2 Kurpfälzisches Museum Heidelberg, Kupferstichkabinett, $S_{4} 8_{32}$

two \& a half leagues"). ${ }^{76}$ The Hammans' drawing, like the Vérité Chrestienne, textually and iconographically interpreted this topic in eschatological terms, as a satanic inversion proving that the French King was the Antichrist. ${ }^{77}$ Moreover, the semantic field of fire in printed news accompanied that of

76 See n. 21 above.

77 La Verite Chrestienne, p. 43; and its translations: De Christelyke Waerheyt, pp. 27-8; Der Christlichen Warheit, pp. 33-4; A New Declaration, p. 14. 


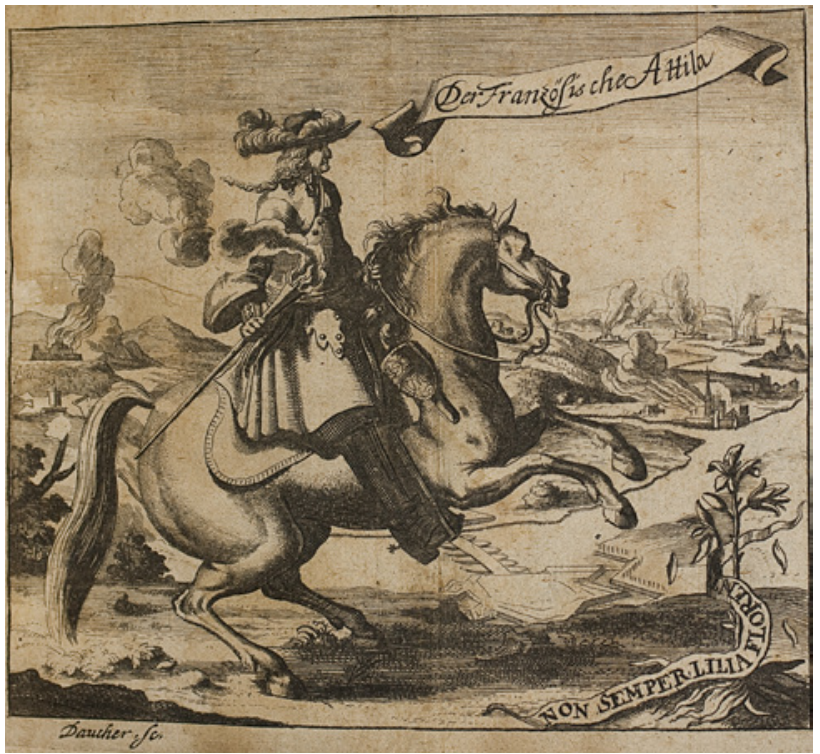

FIGURE 28.3 HAB Wolfenbüttel X 1743

desolation- “desolation", "desolate", "devastation", "make a desert", "reduce to solitude", and so on. It was certainly no coincidence that the Antichrist is also called "the abomination of desolation" (Daniel 11:31, 12:11; Matthew 24:15). In January, the Frankfurt news in the Nouveau Journal Universel announced: "On a jamais vû une plus grande désolation que celle que les François causent dans tout nôtre Voisinage" ("We have never seen a greater desolation such as the one caused by the French in our entire neighbourhood"). In February, the Mannheim news of the Nordirscher Mercurius reported: "Das Verwüsten hat leyder hier noch kein Ende" ("The Desolation here has unfortunately still no End"). In August, the Frankfurt news of the Relations Véritables related: "On vient de recevoir âvis que les François portent par tout la desolation" ("We have been informed that the French are carrying Desolation everywhere"). ${ }^{78}$ And the same term was used in the previously quoted seventh issue of the Lettres sur les matières du temps. Whether the choice of words was deliberate or unconscious is hard to tell. What is certain is that first this vocabulary was employed in all newspapers, protestant as well as catholic, to report war and military violence. It was not a new vocabulary but it gradually came to be attached to the French military operations. Second, this shared vocabulary seemed to make sense for the early modern reader. This news-writing was

$78 \quad N J U, 19$ (20 January 1689); NM, 27 (15 February 1689); RV (24 August 1689). 


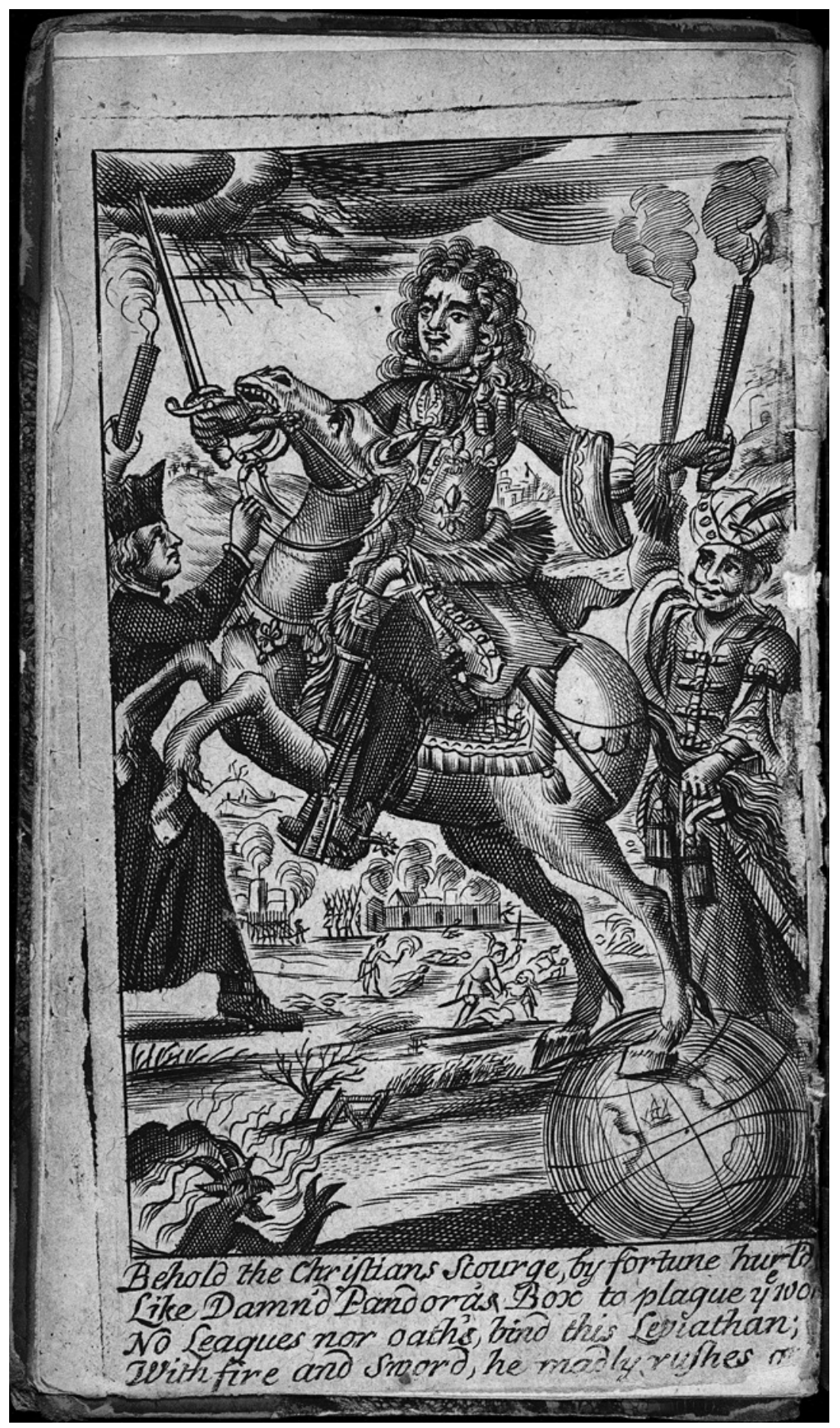

FIGURE 28.4 British Library London R216384 / Bodleian Library Oxford Vet. A3f. 1595 
consistent with an eschatological interpretative pattern which comprehended the enemy as the Antichrist. This old rhetorical and interpretative pattern was revived during the Sun King's reign and reached its apogee during the Nine Years War. Both in England and in the Holy Roman Empire, Louis XIV was identified with the Antichrist. ${ }^{79}$ But above all, this eschatological interpretative pattern had the advantage of providing a potential non-confessional rhetorical point of agreement for a profoundly heterogeneous rising opposition to Louis XIV and a fortiori, in wartime, allies against the Sun King. Primarily defined by his corrupt doctrine, the Antichrist could also be identified by his cruelty and bloodlust. Besides the confessional stakes of the war, which maintained all their importance in the domestic debates, the eschatological frame of reference, thanks to its polemical flexibility, made it possible to overcome doctrinal differences on the international stage and offered a common interpretative pattern to articulate and to denounce the French military operations. ${ }^{80}$

Furthermore, this denunciation mobilised another interpretative pattern, which benefited from the same polemical flexibility and seemed to have become, at the end of the seventeenth century, a shared frame of reference, namely the ideal of justum bellum (or just war) and the still imperfectly formalised laws of war. ${ }^{81}$ The result of an old theological and juridical debate, the

79 On the English case, see: Claydon, Europe and the Making of England, pp. 152-92. On the German case: Franz Bosbach, 'Der französische Erbfeind. Zu einem deutschen Feindbild im Zeitalter Ludwigs XIV', in Feindbilder. Die Darstellung des Gegners in der politischen Publizistik des Mittelsalters und der Neuzeit, ed. Franz Bosbach (Cologne, Weimar, Vienna: Böhlau, 1992), pp. 117-39; Wrede, Das Reich und seine Feinde, pp. 324-545.

8o Claydon, Europe and the Making of England, p. 188.

81 Jean Rouvier, 'Naissance du droit international au XVII ${ }^{\mathrm{e}}$ siècle', Dix-septième siècle, 58.9 (1960), pp. 40-56; Maurice H. Keen, The Laws of War in the Late Middle Ages (London: Routledge, 1965); Frederick Russell, The Just War in the Middle Ages (Cambridge: Cambridge University Press, 1975); Philippe Contamine, 'Lidée de guerre à la fin du Moyen Âge: aspects juridiques et éthiques', AIBC (1979), pp. 70-86; Peter Haggenmacher, Grotius et la doctrine de la guerre juste (Paris: Presses Universitaires de France, 1983); Peter Haggenmacher, 'Mutations du concept de guerre juste de Grotius à Kant', Cahiers de philosophie politique et juridique, 10 (1986), pp. 105-25; Guillaume Bacot, La doctrine de la guerre juste (Paris: Economica, 1989); H. Duchhardt, 'La guerre et le droit des gens dans l'Europe du XVI $^{\mathrm{e}}$ au XVIII ${ }^{\mathrm{e}}$ siècle', in Guerre et concurrence entre Etats européens du XVI ${ }^{e}$ au XVIII ${ }^{e} x v i i i^{e}$ siècle, ed. Philippe Contamine (Paris: Presses Universitaires de France, 1998), pp. 339-64; Heinhard Steiger, 'Ius bändigt Mars. Das klassische Völkerrecht und seine Wissenschaft als frühneuzeitliche Kulturerscheinung', in Krieg und Frieden in der Frühen Neuzeit. Die europäische Staatsordnung und die außereuropäische Welt, ed. Roland G. Asch, W.E. Voß and Martin Wrede (Munich: Fink, 2001), pp. 59-85; Geoffrey Parker, 
ideal just war was based on the principle that war was subject to moral and customary laws (i.e. laws of war), human and Christian, defining a jus ad bellum (laws governing the right to make war) and a jus in bello (laws in wartime) that Louis XIV's army would have infringed. ${ }^{82}$ From the first printed news of them, the French military operations were denounced-implicitly or explicitly - in these terms. After having related "the late Desolation that has been made in the Cities of the Palatinate", the fictional correspondent of the Lettre sur les matières du temps stated that men were "ever laying a great Stress upon the Right wich Justice gives, whether in Matter of War, or in Matter of Peace", and "it is also upon this Foundation, that War has its Laws as well as Peace, not only for the undertaking with Justice and Necessity; but also for the Executing it with Religion and Circumspection, with respect of the Bounds prescribed by common Custom". Before directly commenting on the French military operations, he concluded: "so there is no subverting the Laws established in Military Executions, without making War a perpetual Theatre of Confusion and Horror". ${ }^{83}$ Hence the denunciation of the French military violence took the form of a rhetoric of indignation, of a denunciation of an offence to justice, i.e. to the laws of war and the ideal of just war. Moreover, this rhetoric of indignation was also a rhetoric of scandal. ${ }^{84}$ Indeed, it implied a transgression which threatened the established order and therefore (re)instituted the community, specifically by representing this community as united by an

Success is Never Final: Empire, War and Faith in Early Modern Europe (New York: Basic Books, 2002), pp. 143-68; Stephen C. Neff, War and the Law of Nations: A General History (Cambridge: Cambridge University Press, 2005), esp. 83-158; Ralf Pröve, 'Vom ius ad bellum zum ius in bello. Legitimation militärisches Gewalt in der Frühen Neuzeit', in Gewalt in der Frühen Neuzeit, ed. Claudia Ullbrich, Claudia Jarzebowski and Michaela Hohkamp (Berlin: Duncker \& Humblot, 2005), pp. 261-70; Jean-Mathieu Mattei, Histoire du droit de la guerre. Introduction à l'histoire du droit de la guerre (1700-1819), 2 vols. (Aix-enProvence: Presses Universitaires d'Aix-Marseille, 2006).

82 Solange Rameix, Justifier la guerre. Censure et propagande dans l'Europe du xviie siècle (Rennes: Presses Universitaires de Rennes, 2014), pp. 184-210; also on the English denunciation of the French military operations, pp. 122-34.

$83 L M T$, vol. 2 (31 March 1689), p. 98. Translation: The Dilucidator, The Sixth Letter (1689), pp. $128-9$.

84 On this notion, see: Éric de Dampierre, 'Thèmes pour l'étude du scandale', Annales. Économies, sociétés, civilisations, 9.3 (1954), pp. 328-36; John B. Thompson, Political Scandal. Power and Visibility in the Media Age (Cambridge: Polity Press, 200o); Damien de Blic and Cyril Lemieux, 'Le scandale comme épreuve. Éléments de sociologie pragmatique', Politix, 71 (2005), pp. 9-38. On this notion apply to the desolation of the Palatinate, see: Emilie Dosquet, 'Le ravage du Palatinat au prisme du scandale', Hypothèses, 16 (2013/1), pp. $217-26$. 
apparently unanimous indignation based on the laws of war and the ideal of just war. And at a time where Europe as an idea was gaining ever more coherence and was more and more frequently invoked, beginning to be used as a legitimating figure, the authors adopted a kind of European posture or literary posture of Europe ${ }^{85}$ Relating and denouncing the French military operations gave them an opportunity to conceptualise Europe as a whole defined by an attachment to, and a respect for, the laws of war which, they claimed, were held in common. Authors staged and personified Europe as a scandalisedand thus united-community brought together under a shared ideal of just war. Hence the author of the Vérité chrestienne described a fictional audience of Truth tasked with pleading Justice's cause in the name of an indignant Europe before the Sun King. In the introduction, Truth declared:

Europe (Sir) asks you the reason why so many Infants crush'd Under the Ruins, or devour'd by the Flames? She demands the reasons of many more of your execrable Barbarities, which cannot be express'd, the very thoughts whereof would fill with horrour the most Savage Nations, and Sworn Enemies of God Almighty ${ }^{86}$

This generalisation represents a Europe that is shocked, indignant, accusing, and scandalised. In fact, the aversion was at first individual and private, as in the abundant correspondence of the Princess Palatine, sister-in-law of Louis XIV, in whose name he claimed territories in the Palatine Electorate. On 20 March 1689, she wrote to her aunt, Electress of Hanover, of the "horror" ("Abschew") she felt for "all the desolation" ("alle die Verwüstung"). ${ }^{87}$ The

85 Europa im 17.Jahrhundert. Ein politischer Mythos und seine Bilder, ed. Klaus Bußmann und Elke A. Werner (Stuttgart: Franz Steiner, 2004); Studien zur europäischen Identität im 17. Jahrhundert, ed. Wolfgang Schmale, Rolf Felbinger, Günter Kastner and Josef Köstlbauer (Bochum: Dr. Dieter Winkler, 2004); Olaf Asbach, Europa-Vom Mythos zur Imagined Community? Zur historischen Semantik "Europa" von der Antike bis in 17. Jahrhundert (Hannover: Wehrhahn, 2011); Heinz Duchhardt, "Europa” als Begründungs-und Legitimationsformel in völkerrechtlichen Verträgen der Frühen Neuzeit', in Faszinierende Frühneuzeit: Reich, Frieden, Kultur und Kommunikation, 1500-180o. Festschrift für Johannes Burkhardt zum 65. Geburtstag, ed. Wolfgang E.J. Weber and Regina Dauser (Berlin: Akademie Verlag, 2008), pp. 51-60.

86 We quote here the English translation: $A$ New Declaration, p. 2. For the other versions: $L a$ Verite Chrestienne, pp. 4-5; De Christelyke Waerheyt, p. 4; Der Christlichen Warheit, p. 2.

87 Elizabeth Charlotte of Orleans, Aus den Briefen der Herzogin Elisabeth Charlotte von Orléans an die Kurfürstin Sophie von Hannover, ed. Eduard Bodemann, 2 vols. (Hannover: Hahn, 1891), 1: 102-3. 
author of the Lettres sur les matières du temps asserted at the same time that "letters from that Country [the Palatinate] tell us, That several of those very Persons that have been the Instruments of this sad Spectacle, have had it in such abhorrence, as to make it plain, that with Regret they executed the Orders of the Court".88 The "impartial pen" of the Europäischer Mercurius called for indignation and declared that: "es seynd diese barbarisch- und unmenschliche Proceduren in den Pfaltz/ die billig einen äussersten Eckel und Abscheu wider die Frantzösische Nation bey jederman verursachen sollten" ("the barbaric and inhuman conduct in the Palatinate must reasonably cause everyone an extreme revulsion and horror for the French Nation"). ${ }^{89}$ But the shift towards Europe had already begun and the European posture became a topos of the event. One month later, the Mercure historique et politique, the most famous "historical and political mercure" of the time written by Gatien Courtilz de Sandras, related: "Qu'elle douleur pour [les honêtes gens François] de voir le nom François devenir l'horreur de toute l'Europe" ("What a pain for [the honest French people] to see the name French becoming the horror of all Europe").90 Fifty years later, in a famous turn of phrase, Voltaire wrote that "L'Europe en eut horreur" ("All Europe beheld this action with horror"). ${ }^{91}$

Perhaps Voltaire found inspiration for this phrase in the De Limiers' Histoire de Louis XIV to which he referred several times in his marginal notes. ${ }^{92}$ De Limiers in turn borrowed it from the Mémoires et réflexions sur les principaux événements du règne de Louis XIV of De La Fare. ${ }^{93}$ Moreover

88 LMT, vol. 2 (31 March 1689), p. 99. Translation: The Dilucidator, The Sixth Letter (1689), p. 129.

$89 \quad$ EM, Februarius. Anno M. DC. LXXXIX., p. 69.

$90 \quad$ Jean Lombard, 'Mercure historique et politique 1', in Dictionnaire des journaux; and esp. Brétéché, Les Compagnons de Mercure, esp. pp. 28-32, 37-8, 50-56, 73-4, 243-26o, 297300, 305-9, 321-2; Jean Lombard, Courtilz de Sandras et la crise du roman à la fin du Grand Siècle (Paris: Presses Universitaires de France, 1980); Jean Lombard, 'Gatien Courtilz de Sandras', in Dictionnaire des journalistes; Brétéché, Les Compagnons de Mercure, esp. pp. 73-5, 243-260 and 310-11; Mercure historique et politique, vol. 6 (April 1689), p. 361.

91 Voltaire, Le Siècle de Louis XIV, in Voltaire, CEuvres historiques, ed. René Pomeau (Paris: Gallimard, 1957), p. $77^{2}$.

92 [De Limiers], Histoire de Louis XIV, p. 403: "Cette barbarie inspira de l'horreur à toute l'Europe, contre le Roi, \& contre toute la Nation Françoise". ("This barbarity inspired all Europe with horror, against the King, \& against all the French Nation".)

93 [Charles-Auguste de La Fare], Mémoires et réflexions sur les principaux événements du règne de Louis XIV, Et sur le caractère de ceux quiy ont eu la principale part. Par Mr. L. M. D. L. F. (Rotterdam, 1716), p. 246: "Quoi qu'il en soit, cette cruauté inspira de l'horreur à toute l'Europe contre le Roi, \& contre toute la Nation". ("Be that as it may, this cruelty inspired all Europe with horror against the King, \& againt all the Nation"). 
this play of borrowing, typical of the historical writing of the time, originated in printed news. ${ }^{94}$ Indeed, that De Limiers was the biographer of Tronchin du Breuil undoubtedly explains why he used the Lettres sur les matières du temps in particular, and not another source, to write his Histoire de Louis XIV. ${ }^{95}$ But this use of a periodical as a source for historical writing attests to a fundamental practice of the historical writing of the time. In fact, there was a structural continuum between printed news and history. ${ }^{96}$ Hence in his Histoire de la guerre de 1741, Voltaire observed that: "Des compilations de gazettes et des journaux sous cent titres différents forment presque la seule histoire des changements arrivés de nos jours". "Compilations of gazettes and periodicals under thousands of different titles make up almost the only history of changes that occur in our time"). ${ }^{97}$ As the continuous pagination of the Nouveau Journal Universel indicates, some newspapers were designed to be compiled in volumes. Moreover the founders of the "historical and political mercures" grasped and fully assumed their potential historical function. They aimed at going beyond the ephemeral nature of the news to write "a narrative of the ongoing event" that formed a "history of the European present time" ("histoire du temps présent européen"). ${ }^{98}$ So from the beginning, these mercures were editorially designed to be ultimately compiled and hence to be read as an historical continuity. ${ }^{99}$ In this regard, the role played by the "primary narrative" of the French military actions that was formed by printed news was all the more essential in their historical inscription as a singular event. The French-language histories of the Sun King's reign published abroad from the eighteenth century bear witness to this crucial role. The German-language historical writing of the Desolation follows similar mechanisms. A historical calendar published in 1691 included a version of the Heidelberg's account under the title "Unherhörte

94 Bernard Grosperrin, La représentation de l'histoire de France, $\mathrm{PhD}$ thesis, 2 vols. (Université Paris IV, 1978); Pratiques et concepts de l'histoire en Europe XVI ${ }^{e}-X V I I I^{e}$ siècles, ed. JeanMichel Dufays and Chantal Grell (Paris: Presses Paris Sorbonne, 1990); Chantal Grell, L'histoire entre érudition et philosophie. Étude sur la connaissance historique à l'âge des Lumières (Paris: Presses Universitaires de France, 1993); Jean-Marie Goulemot, Le règne

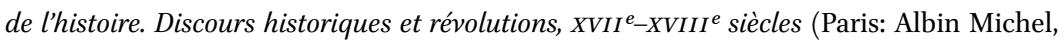
1996).

95 See $n .13$ above.

96 Rétat, 'Les gazettes: de l'événement à l'histoire'; Yardeni, 'Journalisme et histoire contemporaine à l'époque de Bayle'.

97 Quoted by Rétat, 'Les gazettes: de l'événement à l'histoire', p. 25.

98 On this concept, see: Brétéché, Les Compagnons de Mercure, esp. the introduction.

99 Brétéché, Les Compagnons de Mercure, esp. pp. 25-54. 
frantzösische Grausamkeit in der Pfaltz" ("Unheard-of French Cruelty in the Palatinate"). ${ }^{100}$ Likewise versions of this account were published both in the thirteenth volume of the famous chronicle Theatri Europeai in 1698-this time under the title "Grausamkeit des Comte de Melac in der Pfalz" ("Cruelty of the Comte Melac in the Palatinate") — and in the second volume of the no less famous Historischen Labyrinth der Zeit in 1701-this time under the title "Der in der Pfalz mit Brand und Mord wütende Graf von Melac, Frantzösischer Brigadier, Anno 1689" ("The Comte of Melac, French Brigadier, raging with Fire and Death in the Palatinate, Year 1689"). ${ }^{101}$ All these uses endorse and strengthen the exemplary representativeness of Heidelberg and Mélac, as well as the focus on the Palatinate. Through similar mechanisms, it is no coincidence that the vocabulary of fire and desolation used by printed news to relate the French operations became a component of the event's name: variously the "Desolation of the Palatinate", "Verwüstung der Pfalz", "incendie du Palatinat" or "embrasement du Palatinat".

As soon as the French strategy was implemented, the question of its historical representation was raised. In a letter to Louvois on 21 May, the Duc de Duras, commander of the French army in the Rhenish territories, had already concerns for: "le mauvais effet qu'une pareille désolation pourroit faire dans le monde pour sa réputation et pour [la] gloire [de sa majesté]" ("the bad effect that such desolation could have in the world on [her Majesty's] reputation and glory"). ${ }^{102}$ And a few months later, in a German brochure called Concursus creditorum that represented the trial of Louis XIV before Apollo on Mount Parnassus, the Palatinate's inhabitants declared that:

Es bleibt uns nicht übrig/ als daß wir zu ewigen Zeiten ein Spectacul seyn der Frantzösischen Brutalität/ und daß wir durch gantz Europa/ wowir auch zertreuet sind/ umb Rache schreyen/ zu dem der da ausdrücklich sagt: Mein ist die Rache. ${ }^{103}$

(All that remains is for us to be for eternity a sight of the French brutality and to scream for revenge everywhere in Europe, wherever we are scattered, to the one who said expressly: Vengeance is mine.)

\footnotetext{
100 Alten und Neuen Styli Sonderbahrer Historien-Calender Auff das Jahr Christi/ 1691 (Hamburg, [1690]).

101 Theatri Europaei Continuati Dreyzehender Theil (Frankfurt/Main, 1698), pp. 675-7.. H.A. von Ziegler und Kliphausen, Historisches Labyrinth der Zeit (Leipzig, 1701), vol. 2, pp. 1194-6.

102 Defense Historical Service, Vincennes, GR A1 882, 91, Letter of Duras to Louvois, 21 May 1689.

103 Concursus Creditorum (n.p., 1689), p. 38.
} 
With this case of the refugees, we see the shift from what happened to what the news reported, and then to what the pamphleteers sought to effect historically by the act of writing. Hence in his last sentence, Apollo orders that French glory should sink into oblivion and that the perpetual narrative of the horrifying and cruel acts committed by France darken her history from that point on.

Although the coherence of the official French propaganda was (ironically, as Peter Burke has underlined) an undeniably crucial factor in the coherence of the printed opposition against Louis XIV, this coherence also resulted, as Joseph Klaits has suggested, from European news networks. ${ }^{104}$ But the eventbuilding process of the French military operations was certainly not uniform. Although it was undoubtedly characterised by a European dimension, this transnational scale was based on and interacted with domestic scales, which were dealing with the military operations in their own terms and influenced in turn the cross-border processing of the event.

From a certain perspective, Apollo's wishes were partly granted. Although the Sun King did not lose all his glory, he also became "celui dont les armées embrasèrent le Palatinat" ("the one whose armies ravaged the Palatinate"). ${ }^{105}$ In the long term, the event has been (re)appropriated in numerous times and spaces: for instance, these (re)appropriations had a part in constituting the trial of the monarchy during the French Revolution, in Franco-German relations and the building of the German nation state from the Napoleonic wars to the Interwar period, and in debates over the Irish question in the British Empire. As soon as the French military operations occurred, printed news contributed both to their representation and the building of the historical object of the "Desolation of the Palatinate" itself, an object that has become a true "figure of the narrative", epitomising the Sun King's reign and rapidly becoming a signifier of the horror of war. ${ }^{106}$

104 Burke, The Fabrication of Louis XIV, p. 149; Klaits, Printed Propaganda under Louis XIV, p. 22.

105 Joseph de La Vallée, Tableau philosophique du règne de Louis XIV ou Louis XIV jugé par un François libre (Strasbourg, 1791), p. 88.

106 Hervé Drévillon, Batailles (2007; Paris: Le Seuil, 2009), p. 14. 